OPEN ACCESS

Edited by:

Annamaria De Luca, University of Bari Aldo Moro,

Italy

Reviewed by:

Francesco Miceli, University of Naples Federico II,

Bin-Nan Wu Kaohsiung Medical University,

Taiwan

${ }^{*}$ Correspondence:

Balázs Horváth

horvath.balazs@med.unideb.hu

Specialty section:

This article was submitted to

Cardiovascular and

Smooth Muscle Pharmacology,

a section of the journal

Frontiers in Pharmacology

Received: 31 December 2019

Accepted: 18 March 2020

Published: 20 April 2020

Citation:

Horváth $B$, Hézső $T$, Kiss $D$, Kistamás K, Magyar J, Nánási PP and Bányász T (2020) Late Sodium

Current Inhibitors as Potential

Antiarrhythmic Agents.

Front. Pharmacol. 11:413.

doi: 10.3389/fphar.2020.00413

\section{Late Sodium Current Inhibitors as Potential Antiarrhythmic Agents}

\author{
Balázs Horváth ${ }^{1,2^{*}}$, Tamás Hézső ${ }^{1}$, Dénes Kiss ${ }^{1}$, Kornél Kistamás ${ }^{1}$, János Magyar ${ }^{1,3}$, \\ Péter P. Nánási ${ }^{1,4}$ and Tamás Bányász ${ }^{1}$ \\ ${ }^{1}$ Department of Physiology, Faculty of Medicine, University of Debrecen, Debrecen, Hungary, ${ }^{2}$ Faculty of Pharmacy, \\ University of Debrecen, Debrecen, Hungary, ${ }^{3}$ Division of Sport Physiology, University of Debrecen, Debrecen, Hungary, \\ ${ }^{4}$ Department of Dental Physiology and Pharmacology, Faculty of Dentistry, University of Debrecen, Debrecen, Hungary
}

Based on recent findings, an increased late sodium current ( $\left.l_{\mathrm{Na}, \text { late }}\right)$ plays an important pathophysiological role in cardiac diseases, including rhythm disorders. The article first describes what is $I_{N a, l a t e}$ and how it functions under physiological circumstances. Next, it shows the wide range of cellular mechanisms that can contribute to an increased $I_{\mathrm{Na} \text {, late }}$ in heart diseases, and also discusses how the upregulated $I_{\mathrm{Na} \text {,late }}$ can play a role in the generation of cardiac arrhythmias. The last part of the article is about $I_{N a \text {,late }}$ inhibiting drugs as potential antiarrhythmic agents, based on experimental and preclinical data as well as in the light of clinical trials.

Keywords: voltage gated sodium channel, late sodium current, arrhythmias, antiarrhythmic drugs, sodium channel inhibitors

\section{INTRODUCTION}

During the non-pacemaker action potential (AP) in the heart, depolarization of the cell membrane opens voltage gated sodium channels $\left(\mathrm{Na}_{\mathrm{v}}\right)$ for a short period of time (Scanley et al., 1990; Mitsuiye and Noma, 2002) giving rise to the early sodium current peak $\left(\mathrm{I}_{\mathrm{Na} \text {,early }}\right)$. This $\mathrm{I}_{\mathrm{Na} \text {,early }}$ causes the upstroke of the non-pacemaker AP. Through the course of the AP $\mathrm{Na}_{\mathrm{v}}$ channels may recover from inactivation and reopen, generating a sustained current component, called late sodium current $\left(\mathrm{I}_{\mathrm{Na} \text {,late }}\right) . \mathrm{I}_{\mathrm{Na} \text {,late }}$ flows throughout the plateau phase of the AP therefore it significantly contributes to AP morphology, even though its magnitude is only a fraction of $\mathrm{I}_{\mathrm{Na} \text {,early }}$ (Figure 1A).

If $\mathrm{I}_{\mathrm{Na} \text {,late }}$ is increased, it might play a pathophysiological role in acquired cardiac diseases (Figure 1B) such as myocardial ischemia (Maier and Sossalla, 2013) and heart failure (Coppini et al., 2013; Pourrier et al., 2014). In the cardiomyocytes, an upregulated $\mathrm{I}_{\mathrm{Na} \text {,late }}$ hinders repolarization and causes a larger sodium entry, therefore increasing intracellular sodium concentration $\left(\left[\mathrm{Na}^{+}\right]_{\mathrm{i}}\right)$. An increased $\left[\mathrm{Na}^{+}\right]_{\mathrm{i}}$, in turn, leads to a larger intracellular calcium content. These factors together can possibly cause contractile dysfunction (Sossalla et al., 2011), disturbed myocardial energetics (Liu and O'Rourke, 2008) and cardiac arrhythmias (Antzelevitch et al., 2014).

\section{ELECTROPHYSIOLOGICAL IDENTIFICATION OF I INA,LATE}

Mammalian cardiac cells express a wide variety of $\mathrm{Na}_{\mathrm{v}}$ isoforms, differing in unit conductance, voltage sensitivity, kinetics, and drug sensitivity. In the majority of cardiac tissues, the dominant isoform of the pore-forming subunit is $\mathrm{Na}_{\mathrm{v}} 1.5$, which is relatively insensitive to the sodium channel 
toxin tetrodotoxin (TTX) (Gellens et al., 1992; Catterall et al., 2005). Many of the TTX-sensitive ("non-cardiac") $\mathrm{Na}_{\mathrm{v}}$ channels $\left(\mathrm{Na}_{\mathrm{v}} 1.1, \mathrm{Na}_{\mathrm{v}} 1.2, \mathrm{Na}_{\mathrm{v}} 1.3, \mathrm{Na}_{\mathrm{v}} 1.4\right.$, and $\left.\mathrm{Na}_{\mathrm{v}} 1.6\right)$ are also shown to be present in cardiac tissue (Maier et al., 2002; Haufe et al., 2005; Valdivia et al., 2005; Biet et al., 2012; Yang et al., 2012). In nodal tissue $\mathrm{Na}_{\mathrm{v}} 1.1$ and $\mathrm{Na}_{\mathrm{v}} 1.6$ are expressed in the largest quantities. Besides the pore-forming subunit, four auxiliary subunits $\left(\beta_{1}, \beta_{2}\right.$, $B_{3}$, and $B_{4}$ ) and certain scaffolding proteins also participate in building up the whole complex, which also attaches to the cytoskeleton. These molecules can interact with each other and may modify the kinetics and voltage dependence of the actual channel (Malhotra et al., 2001).

Mechanisms that are discussed in the followings may contribute to the profile of $\mathrm{I}_{\mathrm{Na} \text {, late }}$ during the AP. Understanding these mechanisms better might be helpful in developing new antiarrhythmic therapeutic strategies targeting $\mathrm{I}_{\mathrm{Na} \text {,late. }}$

\section{$I_{\text {Na,late }}$ Is Underlain by Different Channel Gating Modes}

At the resting membrane potential, the vast majority of $\mathrm{Na}_{\mathrm{v}} 1.5$ channels are in their closed state. Upon depolarization, $\mathrm{Na}_{\mathrm{v}} 1.5$ channels open up within 1-2 ms after which they inactivate rapidly (Scanley et al., 1990; Mitsuiye and Noma, 2002). This produces $\mathrm{I}_{\mathrm{Na} \text {,early }}$ and the upstroke of the non-pacemaker cardiac AP. During a sustained depolarization, $\mathrm{Na}_{\mathrm{v}} 1.5$ channels can reopen with a small probability. In ventricular myocytes, three modes of Nav1.5 channel activity have been characterized in single-channel experiments: transient mode (TM), burst mode (BM), and late scattered mode (LSM) (Maltsev, 2006).

$\mathrm{I}_{\mathrm{Na} \text {,early }}$ is mainly the result of TM activity, while BM and LSM are responsible for the sustained sodium current, $\mathrm{I}_{\mathrm{Na}}$, late (Figure 1A). The magnitude of the sustained current component is only about $0.5-1 \%$ of $\mathrm{I}_{\mathrm{Na} \text {,early }}$ measured $50 \mathrm{~ms}$ after the onset of the depolarizing pulse (Maltsev, 2006). During a sustained depolarization BM openings rapidly decline in the first tens of milliseconds therefore leaving LSM as the gating mode being mainly responsible for $\mathrm{I}_{\mathrm{Na}}$, late toward the end of the plateau phase.

Mutations of the channel protein and certain diseases can change the contribution of different $\mathrm{Na}_{\mathrm{v}} 1.5$ channel activity patterns to the macroscopic current, therefore increasing $I_{\mathrm{Na} \text {, late }}$ (Bezzina et al., 1999; Valdivia et al., 2005; Wu et al., 2006; Maltsev et al., 2007; Maltsev and Undrovinas, 2008; Song et al., 2008; Maltsev et al., 2009; Xi et al., 2009; Guo et al., 2010; Trenor et al., 2012) (Figure 1B). Apparently, each gating mode has a distinct drug sensitivity or drug affinity as well (Belardinelli et al., 2004; Ravens et al., 2004; Belardinelli et al., 2006). Based on this, selective pharmacological targeting of certain gating modes might have potential antiarrhythmic and/or cardioprotective effects (Belardinelli et al., 2006; Hoyer et al., 2011; Morita et al., 2011).

\section{Window Sodium Current}

The voltage dependence of the steady state activation and inactivation of most $\mathrm{Na}_{\mathrm{v}}$ channels overlaps with each other (Zaza and Rocchetti, 2013). This overlap provides a voltage range ("window") where inactivated $\mathrm{Na}_{\mathrm{v}}$ channels are able to recover from inactivation and then might reopen. When the actual membrane potential falls within this "window" of overlap, a sustained current is evoked. Under physiological circumstances this "window current" mechanism likely plays a limited role in $\mathrm{I}_{\mathrm{Na} \text {,late, }}$ because the $\mathrm{Na}_{\mathrm{v}} 1.5$ voltage "window" is around $-70 \mathrm{mV}$, falling quite far from the AP plateau. Additionally, in the window voltage range, the current density is less than $5 \%$ of the maximum current density in healthy myocytes (Maltsev et al., 1998; Wang et al., 2002; Liu et al., 2007). Hence, the "window current" mechanism is unlikely to be a major determinant of $\mathrm{I}_{\mathrm{Na} \text {,ate }}$ in healthy myocytes. Mutations of channel proteins or altered regulation in certain diseases may shift either the steady-state

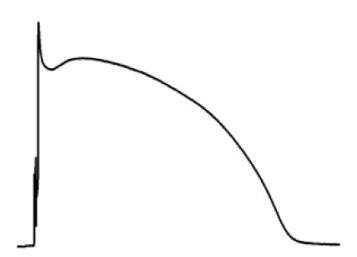

Physiological

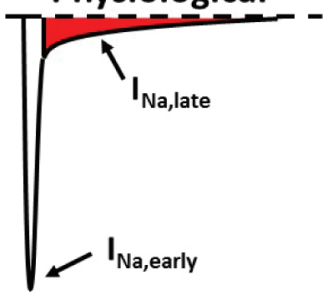

B

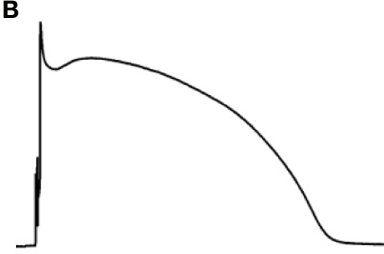

Pathological

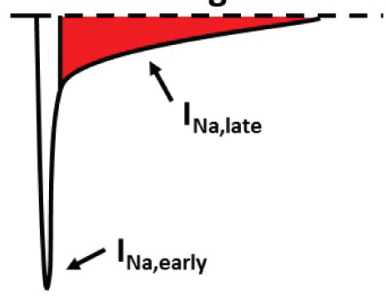

FIGURE 1 | The early and the late component of the sodium current under physiological (A) and pathological (B) conditions. Upper panels: membrane potential; lower panels: sodium current. $I_{\mathrm{Na} \text {,early, }}$ early (peak) component of the sodium current; $I_{\mathrm{Na}}$,ate, late (sustained) component of the sodium current. 
activation or inactivation curves of $\mathrm{Na}_{\mathrm{v}}$ channels to significantly change this voltage window, therefore increasing $\mathrm{I}_{\mathrm{Na}}$,late under these pathological conditions (Wang et al., 1996; Ruan et al., 2009).

\section{Non-Equilibrium Channel Gating}

During the AP of cardiac myocytes, the membrane potential changes continuously. $\mathrm{Na}_{\mathrm{v}}$ channels are incorporated into this dynamic system. It has been proposed by Clancy et al. (2003) that the voltage "history" of the cell membrane can modulate the transition between $\mathrm{Na}_{\mathrm{v}}$ channel states, termed "non-equilibrium gating". As a result, recovery from inactivation is also modulated by the dynamics of voltage change. The theory is supported by experimental data showing that the application of repolarizing voltage ramps or AP shape voltage commands evoke a larger $\mathrm{I}_{\mathrm{Na} \text {, late }}$ compared to conventional square pulses or model simulations where "nonequilibrium gating" is not incorporated into the numerical model (Clancy et al., 2003; Magyar et al., 2004; Horvath et al., 2013).

\section{Non-Cardiac Sodium Channel Isoforms in the Heart}

Epilepsy (Alekov et al., 2000; Akalin et al., 2003) and certain skeletal muscle diseases (Komajda et al., 1980; Pereon et al., 2003) has been associated with pathological ECG recordings. Therefore it seemed possible that non-cardiac sodium channel mutations might cause electrical alterations in the heart. Later, $\mathrm{Na}_{\mathrm{v}} 1.1, \mathrm{Na}_{\mathrm{v}} 1.2, \mathrm{Na}_{\mathrm{v}} 1.3$, $\mathrm{Na}_{\mathrm{v}} 1.4, \mathrm{Na}_{\mathrm{v}} 1.6$, and $\mathrm{Na}_{\mathrm{v}} 1.8$ isoforms have been identified in cardiac tissue (Maier et al., 2002; Haufe et al., 2005; Valdivia et al., 2005; Biet et al., 2012; Yang et al., 2012). Based on the findings of Biet et al., as much as $44 \%$ of $\mathrm{I}_{\mathrm{Na} \text {,late }}$ is due to non-cardiac sodium channels (Biet et al., 2012) in canine ventricular cardiomyocytes. Furthermore, Yang et al. have shown that in mice and rabbit the TTX-resistant $\mathrm{Na}_{\mathrm{v}} 1.8$ provides a substantial amount of $\mathrm{I}_{\mathrm{Na} \text {,late }}$ (Yang et al., 2012). Based on these experimental data, isoform specific sodium channel modulators might provide a valid approach in pharmacological antiarrhythmic therapy (See Non-Cardiac Sodium Channel Inhibitors as Potential Antiarrhythmic Agent for further details).

\section{ROLE OF I NA,LATE IN CARDIAC PHYSIOLOGY}

\section{Role of $\mathrm{I}_{\mathrm{Na} \text {,late }}$ in Cardiac Electrical Activity}

Contribution of $\mathrm{I}_{\mathrm{Na} \text {, late }}$ to cardiac APs was questioned because of its small density. However, the plateau phase of the cardiac AP is shaped by a delicate balance between minuscule inward and outward current fluxes. Therefore even a small change in these currents may significantly alter the duration of the AP

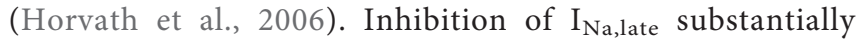
shortens the cardiac AP in the conductive system (Coraboeuf et al., 1979) and in ventricular cells (Kiyosue and Arita, 1989) as well, indicating that $\mathrm{I}_{\mathrm{Na} \text {,late }}$ significantly contributes to determining the duration of the nonpacemaker AP in cardiac myocytes. Recent AP voltage clamp experiments show that the density of $\mathrm{I}_{\mathrm{Na} \text {,late }}$ is of similar magnitude as the major potassium currents in guinea pig (Horvath et al., 2013) and rabbit
(Hegyi et al., 2018) ventricular myocytes. There is a characteristic interspecies difference in the shape of $\mathrm{I}_{\mathrm{Na}}$, late as shown in the case of guinea pig, canine, and human ventricular myocytes (Horvath et al., 2020).

The sustained sodium current is also an important factor in determining electrophysiological properties of sinoatrial node cells (Maier et al., 2003; Lei et al., 2004). Tetrodotoxin, applied in lower than $1 \mu \mathrm{M}$ concentrations, reduces the rate of spontaneous depolarization in sinoatrial node cells (Huang et al., 2015), clearly indicating that non-cardiac $\mathrm{Na}_{\mathrm{v}}$ isoforms also contribute to cardiac automaticity.

Cardiac Purkinje cells have the largest rate-dependence of their AP duration (APD) among cardiomyocytes with fast response APs. Purkinje cell APs are longer at lower stimulation rates, while shorter at higher rates than APs of ventricular cells. It has been shown that $\mathrm{I}_{\mathrm{Na} \text {,late }}$ contributes to this feature by possessing much slower decay and recovery kinetics in Purkinje cells than in ventricular cells. As a result Purkinje cell $\mathrm{I}_{\mathrm{Na} \text {,late }}$ is significantly larger at low heart rates, while smaller at high heart rates compared to ventricular cells. This unique feature predisposes Purkinje cells to serve as triggers in generating arrhythmias (Li et al., 2017).

$\mathrm{I}_{\mathrm{Na} \text {,late }}$ plays a role in forming the atrial AP as well (Burashnikov and Antzelevitch, 2013; Luo et al., 2014). $\mathrm{I}_{\mathrm{Na} \text {,late }}$ is expected to be larger in atria than in ventricles because $\mathrm{I}_{\mathrm{Na}}$, early density is greater in atrial cells under similar conditions ( $\mathrm{Li}$ et al., 2002; Burashnikov et al., 2007), suggesting a higher sodium channel expression in atrial cells. On the other hand, an overall more positive membrane potential, and a more negative steady-state inactivation voltage of the sodium current ( $\mathrm{Li}$ et al., 2002; Burashnikov et al., 2007) in the atrial cells reduce the availability of the sodium channels (Burashnikov and Antzelevitch, 2008). In one set of experiments by Luo et al. maximum $\mathrm{I}_{\mathrm{Na} \text {,late }}$ density has been reported to be greater in rabbit left atrial myocytes than in ventricular cells (Luo et al., 2014) and in a different investigation the two cell types seemed to be similar in this matter (Persson et al., 2007). APs are shorter in the atria compared to the ventricles reducing the amount of $\mathrm{Na}^{+}$ influx through $\mathrm{I}_{\mathrm{Na}}$,late in the former (Burashnikov and Antzelevitch, 2013).

\section{$I_{\mathrm{Na}, \text { late }}$ Plays a Significant Role in the Sodium Homeostasis of Cardiomyocytes}

$\left[\mathrm{Na}^{+}\right]_{\mathrm{i}}$ is set by a dynamic equilibrium of the influx of $\mathrm{Na}^{+}$into the cell and efflux of $\mathrm{Na}^{+}$to the interstitial space. The $\left[\mathrm{Na}^{+}\right]_{\mathrm{i}}$ of non-paced ventricular myocytes is around $4-8 \mathrm{mM}$ in guineapig, rabbit, and canine; and about twice as high in rat and mouse (9-14 mM) (Despa and Bers, 2013). In non-paced human myocytes $\left[\mathrm{Na}^{+}\right]_{\mathrm{i}}$ is thought to be in the $4-10 \mathrm{mM}$ range.

$\mathrm{Na}^{+}$can enter into the cell through $\mathrm{Na}^{+}$channels, $\mathrm{Na}^{+} / \mathrm{Ca}^{2+}$ exchanger (NCX) and $\mathrm{Na}^{+} / \mathrm{H}^{+}$exchanger (NHE). $\mathrm{Na}^{+}$leaves the cell mainly via the $\mathrm{Na}^{+} / \mathrm{K}^{+}$pump (NKP), but the reverse mode NCX is also responsible for a moderate $\mathrm{Na}^{+}$efflux during the first few milliseconds of the cardiac AP. Furthermore, $\mathrm{Na}^{+} / \mathrm{HCO}_{3}{ }^{-}$ cotransport, $\mathrm{Na}^{+} / \mathrm{Mg}^{2+}$ exchange, and $\mathrm{Na}^{+} / \mathrm{K}^{+} / 2 \mathrm{Cl}^{-}$cotransport can play a role in the sodium homeostasis of cardiomyocytes to a 
small extent (Despa and Bers, 2013). It also has to be mentioned that $\mathrm{Na}^{+}$concentrations between the cytosol and intracellular organelles are continuously balanced.

Upon pacing, $\left[\mathrm{Na}^{+}\right]_{\mathrm{i}}$ increases with increasing stimulation frequency, caused by the larger $\mathrm{Na}^{+}$entry through $\mathrm{Na}^{+}$channels and NCX. In paced, single cardiac cells approximately $25 \%$ of the $\mathrm{Na}^{+}$entry is mediated by $\mathrm{Na}_{\mathrm{v}}$ channels (Despa and Bers, 2013). The $\mathrm{Na}^{+}$entry through $\mathrm{Na}_{\mathrm{v}}$ channels is about equally distributed between $\mathrm{I}_{\mathrm{Na} \text {,early }}$ and $\mathrm{I}_{\mathrm{Na} \text {,late }}$ (Makielski and Farley, 2006; Zaza and Rocchetti, 2013; Despa and Bers, 2013; Shryock et al., 2013), however this contribution can change at different heart rates (see Heart Rate and AP Duration Influences $I_{N a \text {,late }}$ for details). The higher $\mathrm{Na}^{+}$influx into paced cells is matched by an increased efflux through an elevated NKP activity. This is mainly caused by the increased $\left[\mathrm{Na}^{+}\right]_{\mathrm{i}}$ itself, but nitric oxide-, and phospholemman-dependent mechanisms can also add to this effect (Despa and Bers, 2013).

\section{$\mathrm{Na}^{+}$and $\mathrm{Ca}^{2+}$ Homeostasis Is Linked in Cardiomyocytes The Direct Connection Between $\mathrm{Na}^{+}$and $\mathrm{Ca}^{2+}$ Homeostasis: $\mathrm{Na}^{+} / \mathrm{Ca}^{2+}$ Exchanger}

The NCX is a secondarily active transporter that carries $1 \mathrm{Ca}^{2+}$ and $3 \mathrm{Na}^{+}$at the same time (Janvier and Boyett, 1996; Fujioka et al., 2000; Sipido et al., 2007; Despa and Bers, 2013; Ginsburg et al., 2013). The NCX function is determined by the relation of the actual membrane voltage and the sum of the actual electrochemical gradients of $\mathrm{Ca}^{2+}$ and $\mathrm{Na}^{+}$. The main role of NCX is to remove $\mathrm{Ca}^{2+}$ from the cells by utilizing the potential energy present in the form of $\mathrm{Na}^{+}$gradient ("forward mode"). Besides this mode, in the first few milliseconds of the AP, NCX mediates $\mathrm{Na}^{+}$extrusion from the cell and $\mathrm{Ca}^{2+}$ entry into the cytosol ("reverse mode").

\section{$\mathrm{I}_{\mathrm{Na} \text {,late }}$ Facilitates $\mathrm{Ca}^{2+}$ Influx via L-Type Calcium Channels}

Being an inward current, $\mathrm{I}_{\mathrm{Na} \text {, late }}$ depolarizes the membrane, causing an increased membrane potential throughout the plateau phase and a longer AP. The more time the membrane spends in a depolarized state (above $+40 \mathrm{mV}$ ) the higher the possibility that L-type calcium channels can open or re-open. It is well documented with AP voltage clamp technique that the Ltype calcium current is flowing throughout the AP plateau (Linz and Meyer, 1998; Linz and Meyer, 2000; Banyasz et al., 2003; Fulop et al., 2004; Banyasz et al., 2012). Therefore a longer AP inevitably results in a larger $\mathrm{Ca}^{2+}$ entry to the myocyte.

\section{Heart Rate and AP Duration Influences $I_{\mathrm{Na} \text {,late }}$}

Heart rate determines the magnitude of $\mathrm{I}_{\mathrm{Na} \text {,late }}$ Like many electrophysiological characteristics of cardiac cells (Banyasz et al., 2009), $I_{\mathrm{Na} \text {,late }}$ is reverse-rate dependent, so the faster the stimulation rate the smaller the current density will be (Nagatomo et al., 2002; Wu et al., 2011). However, with increasing heart rate the density of $\mathrm{I}_{\mathrm{Na} \text {,early }}$ and maximum rate of depolarization during the AP upstroke $\left(\mathrm{V}_{\text {max }}\right.$; an AP parameter determined by $\mathrm{I}_{\mathrm{Na} \text {,early }}$ ) does not decrease that much (Nagatomo et al., 2002). This is because recovery of $I_{N a, l a t e}$ is much slower than $\mathrm{I}_{\mathrm{Na} \text {,early }}$ (Carmeliet, 2006). At higher heart rates this feature of the two sodium current components also results in a decreasing contribution of $\mathrm{I}_{\mathrm{Na} \text {, late }}$ to the overall $\mathrm{Na}^{+}$ influx. Under these conditions, the more frequent AP upstrokes cause a greater $\mathrm{Na}^{+}$entry through $\mathrm{I}_{\mathrm{Na} \text {,early, and there is a }}$ reduction of $\mathrm{I}_{\mathrm{Na} \text {, late }}$ density because of the very slow $\mathrm{I}_{\mathrm{Na}}$, late recovery kinetics. Moreover, rate-dependent changes of the AP length also influence $\mathrm{Na}^{+}$entry. At high heart rates APs are shorter, therefore $\mathrm{I}_{\mathrm{Na} \text {,late }}$ is active for a shorter time, accounting for a further reduction of $\mathrm{Na}^{+}$influx through the already smaller $\mathrm{I}_{\mathrm{Na} \text {,late }}$. At the same time, extrusion of $\mathrm{Na}^{+}$by the NKP is reduced at high pacing rates (Despa and Bers, 2013) leading to a ratedependent $\left[\mathrm{Na}^{+}\right]_{\mathrm{i}}$ loading in isolated cells. It must also be noted that this phenomenon is largely offset or may not occur at all during $\beta$-adrenergic stimulation because it augments NKP activity through phospholemman (Cheung et al., 2010).).

As it is described in the previous section, APD influences $\mathrm{I}_{\mathrm{Na} \text {,late}}$ : the shorter the AP the smaller the $\mathrm{Na}^{+}$flux through $\mathrm{I}_{\mathrm{Na} \text {,late }}$ is. Therefore under any conditions that result in a shorter AP the contribution of $\mathrm{I}_{\mathrm{Na} \text {, late }}$ to the overall $\mathrm{Na}^{+}$influx will be smaller. This fact, together with significant differences in heart rate underlies differences in $\mathrm{I}_{\mathrm{Na} \text {,late }}$ between species having short APs (e.g.: rats or mice) and long APs (guinea pig, rabbit, pig, human, etc.). In rats and mice both $\mathrm{I}_{\mathrm{Na}}$, late and $\mathrm{Na}^{+}$influx driven by $I_{\mathrm{Na} \text {,late }}$ should be much smaller than in species having long APs.

\section{Modulation of I $\mathrm{Na}$,late Cytosolic $\mathrm{Ca}^{2+}$ Modulates $\mathrm{I}_{\mathrm{Na} \text {,late }}$ in a Complex Way} $\mathrm{Ca}^{2+}$ is the key player in the excitation-contraction coupling of cardiac cells and it also regulates many other cellular functions including sarcolemmal transport mechanisms. $\mathrm{Na}_{\mathrm{v}}$ channels are regulated by the individual and cooperative actions of $\mathrm{Ca}^{2+}$, calmodulin (CaM), and $\mathrm{Ca}^{2+}$-CaM dependent protein kinase II (CaMKII) as well (Bers and Grandi, 2009; Maier, 2011; Scheuer, 2011). Signaling through the $\mathrm{Ca}^{2+}-\mathrm{CaM}-\mathrm{CaMKII}$ pathway is thought to facilitate the sodium current, especially $\mathrm{I}_{\mathrm{Na}}$, late (Maltsev et al., 2008; Maltsev et al., 2009; Bers and Grandi, 2009).

\section{$\mathrm{Na}_{\mathrm{v}}$ Channels, $\mathrm{Ca}^{2+}$ and $\mathrm{CaM}$}

Motifs with $\mathrm{Ca}^{2+}$ binding (EF hand) as well as CaM binding (IQ motifs) capabilities are present in the $\mathrm{Na}_{\mathrm{v}} 1.5$ channel structure. Some groups have shown that $\mathrm{Ca}^{2+}$ alone can regulate sodium channels (Wingo et al., 2004), while other results support that $\mathrm{Ca}^{2+}$ is not capable of regulating $\mathrm{Na}_{\mathrm{v}}$ channels directly; the regulation is mediated via $\mathrm{Ca}^{2+}$-CaM complex (Tan et al., 2002; Kim et al., 2004). Besides the exact regulatory mechanism, the general agreement is that when $\mathrm{Ca}^{2+}$ is elevated the SSI curve shifts toward more positive voltages (Sarhan et al., 2012), although this is a largely negligible effect at physiologically relevant $\mathrm{Ca}^{2+}$ concentrations in wild type channels. However, under conditions when $\mathrm{Ca}^{2+}$ or $\mathrm{CaM}$ sensing regions are mutated or when the $\mathrm{Ca}^{2+}$ sensitivity of $\mathrm{Na}_{\mathrm{v}}$ channels are severely altered, diverse functional disturbances may arise leading to an increased $\mathrm{I}_{\mathrm{Na} \text {, late. }}$ 


\section{$\mathrm{Ca}^{2+}$-CaM Dependent Protein Kinase II (CaMKII)}

Besides the direct regulation of $\mathrm{Na}_{\mathrm{v}}$ channels, the $\mathrm{Ca}^{2+}-\mathrm{CaM}$ complex activates CaMKII $\delta_{\mathrm{C}}$ that also modulates these channels (Zhang and Brown, 2004; Anderson, 2005; Bers and Grandi, 2009). The active CaMKII is a Ser/Thr kinase that can phosphorylate $\mathrm{Na}_{\mathrm{v}} 1.5$ channels on at least three amino acid residues (Grandi and Herren, 2014). While there is an ongoing debate about the exact role of these phosphorylation sites in channel gating, all the studies agree on that activation of CaMKII increases $\mathrm{I}_{\mathrm{Na} \text {,late. }}$

\section{Complex Modulation by $\beta$-Adrenergic Stimulation}

In a meticulous set of AP voltage clamp experiments, Hegyi et al. (Hegyi et al., 2018) showed how different downstream elements of the $\beta$-adrenergic pathway regulate $\mathrm{I}_{\mathrm{Na} \text {,late }}$ in rabbit ventricular myocytes. Protein kinase A, CaMKII, Epac, nitrosylation, as well as reactive oxygen species (ROS) contributed to the upregulation of $\mathrm{I}_{\mathrm{Na} \text {, late }}$ during different phases of the ventricular AP.

\section{Cellular Metabolites}

ROS and $\mathrm{H}_{2} \mathrm{O}_{2}$ increase $\mathrm{I}_{\mathrm{Na} \text {,late }}$ (Song et al., 2004; Song et al., 2006; Sossalla et al., 2008). Some results suggest that CaMKII can be involved in $\mathrm{I}_{\mathrm{Na} \text {,late }}$ facilitation observed in the presence of oxygen free radicals (Wagner et al., 2011), because ROS can also activate CaMKII (Erickson et al., 2008). See (Wagner et al., 2013) for a detailed review.

Acidosis also modulates $\mathrm{Na}_{\mathrm{v}}$ channels (Murphy et al., 2011; Jones et al., 2011; Jones et al., 2013a; Jones et al., 2013b). Acidosis caused a rightward shift in steady-state activation, but not in steady-state inactivation in isolated canine ventricular myocytes therefore reducing $\mathrm{I}_{\mathrm{Na} \text {,late }}$ (Murphy et al., 2011).

Many studies have found that hypoxia increases $\mathrm{I}_{\mathrm{Na} \text {,late }}(\mathrm{Ju}$ et al., 1996; Carmeliet, 1999; Harnmarstrom and Gage, 2002; Wang et al., 2007; Shimoda and Polak, 2011; Tang et al., 2012). Following a 15 minute hypoxic period, Wang et al. reported an increased BM channel activity, a plausible explanation of the increased $\mathrm{I}_{\mathrm{Na} \text {,late }}$.

Intermediary lipid metabolites shown to increase $\mathrm{I}_{\mathrm{Na} \text {,late }} \mathrm{Na}_{\mathrm{v}}$ channels treated with lysophosphatidylcholine exhibited a sustained BM channel activity (Burnashev et al., 1991; Undrovinas et al., 1992), while palmitoylcarnitine induced a slowly inactivating sodium current (Wu and Corr, 1994). According to more recent data, poly-unsaturated fatty acids (docosahexaenoic acid and eicosapentaenoic acid) reduce both $I_{\mathrm{Na} \text {,early }}$ and $\mathrm{I}_{\mathrm{Na} \text {,late }}$ (Pignier et al., 2007). According to the authors, the reduction is caused by a decreased overlap between the steady-state activation and inactivation voltage range.

Nitric oxide (NO) has been shown to enhance $\mathrm{I}_{\mathrm{Na}}$,late (Ahern et al., 2000). The neural NO synthase (nNOS) belongs to the huge macromolecular complex of $\mathrm{Na}_{\mathrm{v}} 1.5$, with caveolin-3 and $\alpha 1$-syntrophin among some additional proteins (Cheng et al., 2013).

\section{Other Mechanisms}

\section{Transcriptional Regulation}

The possible promoter regions and their role in the regulation of human SCN5A gene transcription has already been reported. (Yang et al., 2004; van Stuijvenberg et al., 2010) Recent studies have shown that the zinc-finger transcription factor, GATA4 (Tarradas et al., 2017), and the myocyte enhancing factor-2C (MEF2C) enhances SCN5A transcription (Zhou et al., 2018). However, most likely many other transcription factors are involved in the transcriptional regulation of the SCN5A gene.

\section{Glycosylation}

Some amino acid motifs found in the $\mathrm{Na}_{\mathrm{v}} 1.5$ protein are subject to $\mathrm{N}$-glycosylation. Carbohydrates account for an about $5 \%$ of the total mass of $\mathrm{Na}_{\mathrm{v}}$ channels in the rat heart (Cohen and Levitt, 1993). The lack of channel glycosylation caused shifts toward positive voltages in both steady state activation and inactivation curves when naturally sialic-acid deficient channels were used (Zhang et al., 1999), or when these carbohydrate residues were removed by enzymatic treatment (Ufret-Vincenty et al., 2001) Glycosylation also seem to be involved in channel trafficking (Mercier et al., 2015; Cortada and Brugada, 2019)

\section{Protein Kinase C}

Upon protein kinase $\mathrm{C}$ activation, $\mathrm{Na}^{+}$channels are internalized from the plasma membrane (Hallaq et al., 2012). For the process, both channel phosphorylation on S1503 and ROS are required (Liu et al., 2017).

\section{Phosphorylation on Tyrosine Residues}

The "Fyn" tyrosine kinase phosphorylates $\mathrm{Na}_{\mathrm{v}} 1.5$ channels on the Y1495 Tyr residue, located in the III-IV linker domain. This tyrosine residue helps with anchoring $\mathrm{Ca}^{2+} / \mathrm{CaM}$ to the inactivation gate of the channel (Sarhan and Van Petegem, 2009). When Fyn phosphorylates the channel on Y1495, it increases the window voltage range by shifting the steady-state inactivation toward more positive potentials (Ahern et al., 2005), therefore resulting in an enhanced $\mathrm{I}_{\mathrm{Na} \text {, late. }}$

\section{Arginine Methylation}

There are three known arginine residues in $\mathrm{Na}_{\mathrm{v}} 1.5$ (R513, R526, and R680), that are subject to methylation (Beltran-Alvarez et al., 2011). These residues are found in the domain I and domain II linker region. There are two known mutations of these arginines (namely $\mathrm{R} 526 \mathrm{H}$ and $\mathrm{R} 680 \mathrm{H}$ ) that cause Brugada (Kapplinger et al., 2010) and LQT3 syndromes (Wang et al., 2007), respectively.

\section{Mechanosensitivity}

Mechanical stimuli also affect channel gating in $\mathrm{Na}_{\mathrm{v}} 1.5$ channels. Beyder et al. investigated this phenomenon both in an expression system (Beyder et al., 2010) and in isolated mouse ventricular cells (Beyder et al., 2012). The pressure ramp applied by the authors caused a $235 \%$ increase in LSM Na 1.5 channel openings suggesting that $\mathrm{I}_{\mathrm{Na} \text {,late }}$ is enhanced by mechanical stress. Similar mechanical effects can modify certain signal transduction mechanisms like nNOS and CaMKII (Jian et al., 2014), which can, in turn, increase $\mathrm{I}_{\mathrm{Na} \text {,late }}$. 


\section{THE ROLE OF SODIUM HOMEOSTASIS AND ELEVATED I INA,LATE IN CARDIAC ARRHYTHMIAS}

The pathophysiology of cardiac arrhythmias is based on the classical concept of "arrhythmic triad"; combination of a proarrhythmic substrate, a trigger, and the modulating effect of the autonomic nervous system (Merchant and Armoundas, 2012). The exact combination depends on etiology, cardiac-, and extracardiac comorbidities. Abnormal $\left[\mathrm{Na}^{+}\right]_{\mathrm{i}}$ homeostasis can play a role in creating an arrhythmia-prone substrate as well as in generating a trigger for the rhythm disorder. The discussed mechanisms are summarized on Figure 2.

\section{$\left[\mathrm{Na}^{+}\right]_{\mathrm{i}}$ Increases in Many Cardiac Pathologies}

Compared to non-failing myocytes, $\left[\mathrm{Na}^{+}\right]_{\mathrm{i}}$ is about $2-6 \mathrm{mM}$ larger in myocytes from failing hearts (Pieske et al., 2002; Despa et al., 2002; Schillinger et al., 2006; Louch et al., 2010). In a pressure- and volume-overload rabbit HF model, Despa et al. have found an increased TTX-sensitive $\mathrm{Na}^{+}$influx (Despa et al., 2002). Interestingly, this larger influx was present not only in electrically stimulated myocytes, but in non-paced cells as well. In paced cells the most plausible candidate of this increased TTX-sensitive $\mathrm{Na}^{+}$influx is $\mathrm{I}_{\mathrm{Na} \text {,late }}$. However, the underlying mechanism of this influx is not yet understood completely in resting myocytes.

\section{$\mathrm{I}_{\mathrm{Na}, \text { late }}$ Can Contribute to the Elevated $\left[\mathrm{Na}^{+}\right]_{\mathrm{i}}$}

Many cardiac diseases are associated with an increased $\mathrm{I}_{\mathrm{Na} \text {, late }}$. The list contains cardiac myocytes originating from end-stage HF (Maltsev et al., 1998; Maltsev et al., 2007) and postmyocardial infarction (Huang et al., 2001) preparations as well as animal HF models (Valdivia et al., 2005; Maltsev et al., 2007). The larger $\mathrm{I}_{\mathrm{Na} \text {,late }}$ can be caused by several pathophysiologic factors including oxidative stress (ROS (Song et al., 2006; Sossalla et al., 2008) and NO (Ahern et al., 2000) mainly by Snitrosylation of the $\mathrm{Na}_{\mathrm{v}} 1.5$ channels (Cheng et al., 2013)), hypoxia (Carmeliet, 1999; Tang et al., 2012), mechanical stress (Beyder et al., 2012), and certain ischemic metabolites, for example oxidized lipids (Burnashev et al., 1991). Looking at gating modes in single $\mathrm{Na}_{\mathrm{v}} 1.5$ channels, enhanced $\mathrm{I}_{\mathrm{Na}}$,late is likely underlain by an increased number of BM and LSM openings (Undrovinas et al., 2002; Maltsev, 2006) in HF.

The $\mathrm{Ca}^{2+}-\mathrm{CaM}-\mathrm{CaMKII}$ signal transduction pathway is upregulated in HF (Bers, 2010), and this pathway has been shown to increase $\mathrm{I}_{\mathrm{Na} \text {,late }}$ (Tan et al., 2002; Wagner et al., 2006; Ashpole et al., 2012; Ma et al., 2012). Oxidation activates CaMKII (Wagner et al., 2011) and keeps it constitutively active. The enhanced CaMKII-mediated $\mathrm{Na}_{\mathrm{v}} 1.5$ phosphorylation, therefore, certainly takes part in increasing $\mathrm{I}_{\mathrm{Na}}$,ate under oxidative stress. Recent studies have found that $\mathrm{Na}_{\mathrm{v}} 1.8$ expression is significantly up-regulated, while $\mathrm{Na}_{\mathrm{v}} 1.5$ is reduced in human left ventricular hypertrophy (Ahmad et al., 2019) and HF (Dybkova et al., 2018).

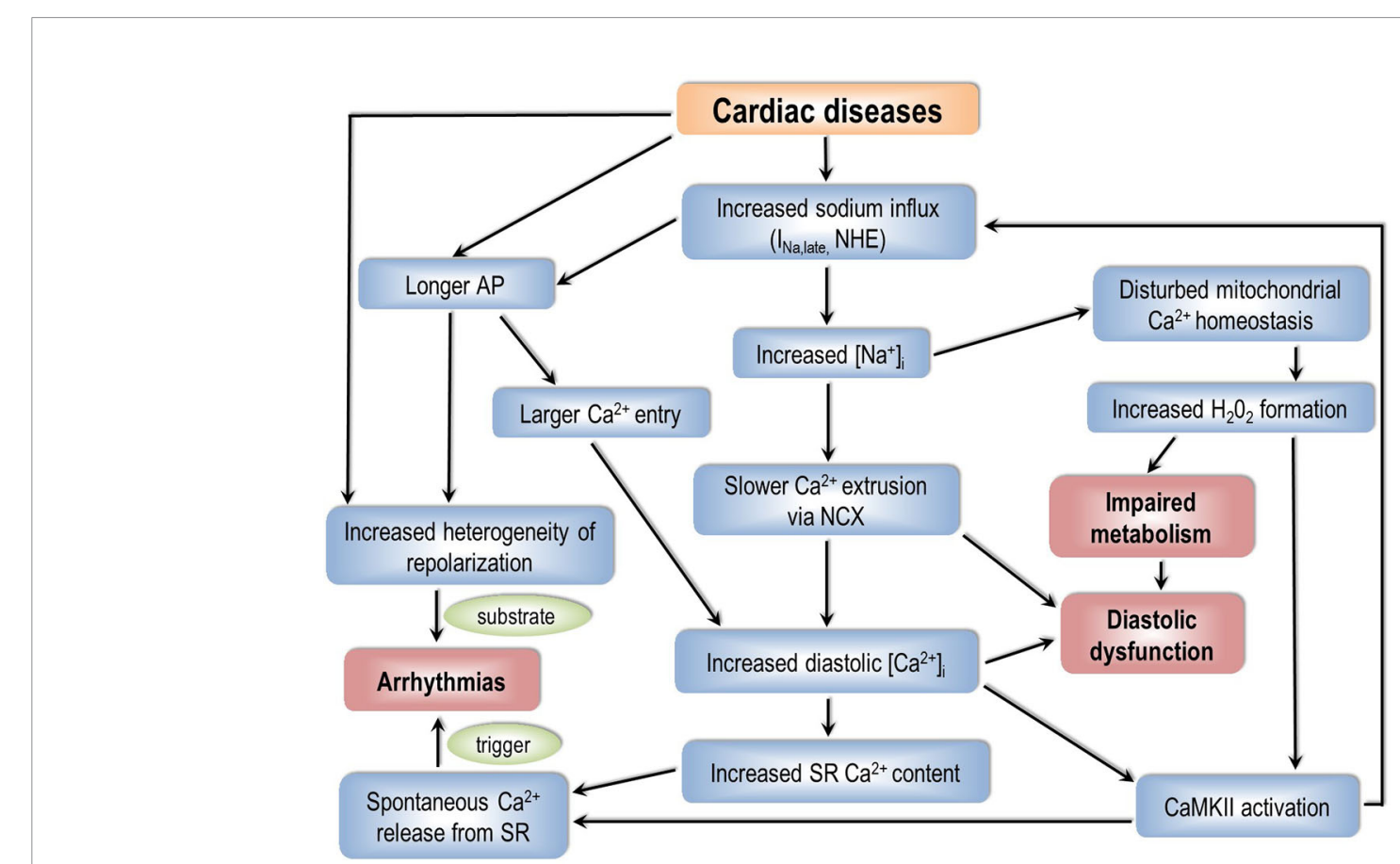

FIGURE 2 | How can an impaired sodium homeostasis of cardiac myocytes lead to arrhythmias? AP, action potential; $\mathrm{NHE} \mathrm{Na}^{+} / \mathrm{H}^{+}$exchanger; $\left[\mathrm{Na}^{+}\right]_{\mathrm{i}}$, intracellular sodium concentration; $\mathrm{NCX}, \mathrm{Na}^{+} / \mathrm{Ca}^{2+}$ exchanger; $\left[\mathrm{Ca}^{2+}\right]_{i}$, intracellular calcium concentration; SR, sarcoplasmic reticulum; CaMKII, calcium/calmodulin dependent protein kinase II. 


\section{The Vicious Circle of CaMKII $-I_{\mathrm{Na} \text {,late }}$ $\left[\mathrm{Na}^{+}\right]_{i}-\left[\mathrm{Ca}^{2+}\right]_{\mathrm{i}}-\mathrm{CaMKII}$}

When $\left[\mathrm{Na}^{+}\right]_{\mathrm{i}}$ is elevated, it makes the NCX forward mode energetically less favorable, therefore a smaller amount of $\mathrm{Ca}^{2+}$ will leave the cell through NCX. This causes an increased $\left[\mathrm{Ca}^{2+}\right]_{i}$ load, and therefore further activates CaMKII, leading to enhanced phosphorylation of CaMKII targets such as $\mathrm{Na}_{\mathrm{v}} 1.5$. This, in turn, increases $I_{N a, \text { late, }}$, which further elevates $\left[\mathrm{Na}^{+}\right]_{i}$ finally creating an arrhythmogenic vicious circle (Grandi and Herren, 2014). By using genetic (LQT3 mutation) as well as pharmacological (anemone toxin-II, ATX-II) approaches to increase $\mathrm{I}_{\mathrm{Na} \text {,late }}$, and therefore achieve $\left[\mathrm{Na}^{+}\right]_{\mathrm{i}}$ loading, Yao et al. described this feedback (Yao et al., 2011). These conditions lead to the vicious circle described above, and as a result, arrhythmias can be generated because of an increase in the CaMKIIdependent phosphorylation of phospholamban and RyRs.

\section{$\left[\mathrm{Na}^{+}\right]_{\mathrm{i}}-$ Mitochondrial $\left[\mathrm{Ca}^{2+}\right]-$ Oxidative Stress - CaMKII-I $\mathrm{Na}_{\mathrm{Nate}}-\left[\mathrm{Na}^{+}\right]_{\mathrm{i}}$ Feedback}

The mitochondrial NCX dynamically equilibrate concentrations of $\mathrm{Ca}^{2+}$ and $\mathrm{Na}^{+}$of the mitochondrion and the cytosol. $\mathrm{Ca}^{2+}$ in the mitochondrion plays a role in determining the production of ATP and ROS by regulating the expression of enzymes involved in oxidative phosphorylation (Yang et al., 2014). If $\left[\mathrm{Na}^{+}\right]_{\mathrm{i}}$ is elevated, it will impair $\mathrm{Ca}^{2+}$ accumulation in the mitochondrion at high pacing rates, leading to a decrease in $\mathrm{NADH} / \mathrm{NAD}^{+}$redox potential. This increases $\mathrm{H}_{2} \mathrm{O}_{2}$ generation in the cells (Liu and O'Rourke, 2008), causing oxidative stress and thereby directly and indirectly (through CaMKII (Erickson et al., 2008)) activating $\mathrm{I}_{\mathrm{Na} \text {, late. }}$. Finally, the process leads to a further increase in $\left[\mathrm{Na}^{+}\right]_{\mathrm{i}}$ (Wagner et al., 2011). This shows that, similar to an elevated $\left[\mathrm{Na}^{+}\right]_{\mathrm{i}}$, CaMKII activation can be caused by and can also lead to an increased ROS production.

\section{Arrhythmogenic Consequences of an Increased $\mathrm{I}_{\mathrm{Na}, \text { late }}$ and $\left[\mathrm{Na}^{+}\right]_{\mathrm{i}}$}

Many inherited and acquired diseases can lead to a longer ventricular repolarization, presented as long QT (LQT) syndromes (El-Sherif et al., 2019; Locati et al., 2019). The inherited LQT3 syndrome is caused by an increased $\mathrm{I}_{\mathrm{Na} \text { alate }}$ because of a mutant, much slower inactivating $\mathrm{Na}_{\mathrm{v}} 1.5$ channel. Acquired LQTs include for example heart failure (Maltsev et al., 1998; Maltsev et al., 2007; Coppini et al., 2013), myocardial ischemia and post-infarction state (Huang et al., 2001; RiveraFernandez et al., 2016), and type 2 diabetes mellitus (Ninkovic et al., 2016).

Under physiological conditions there is a fine balance between the inward and outward currents during the AP plateau. During the plateau phase the impedance of the membrane is large, therefore even a small change in the delicate balance can lead to a marked change in AP duration. In this setting, the depolarizing drive caused by an increased $\mathrm{I}_{\mathrm{Na} \text {,late }}$ causes a longer AP (Studenik et al., 2001; Horvath et al., 2013), as well as under a longer AP, $\mathrm{I}_{\mathrm{Na} \text {,late }}$ will generate a larger $\mathrm{Na}^{+}$influx. Even in normal hearts, both APD and $\mathrm{I}_{\mathrm{Na} \text {,late }}$ is greater in Purkinje fibers and in " $\mathrm{M}$ " cells than in the rest of the myocardium contributing to the physiological heterogeneity of repolarization. LQT syndromes increase both the spatial heterogeneity of repolarization (Maltsev et al., 2007) and the temporal variability of repolarization (El-Sherif et al., 2019) and therefore can present an arrhythmogenic substrate. This can be further exaggerated by bradycardia, where the APs are already long, and having larger heterogeneity (Szentandrassy et al., 2015). Cardiac diseases can also provide the proarrhythmic substrate in the form of temporal repolarization heterogeneity, "repolarization alternans" (Bonatti et al., 2014; Justo et al., 2016) which phenomenon is more pronounced in tachycardia.

The trigger is also highly rate-dependent. At low heart rates, where the cardiac APs are already long even under physiological conditions, an augmented $\mathrm{I}_{\mathrm{Na} \text {, late }}$ can further prolong repolarization therefore increasing the probability of early afterdepolarizations (EADs), and the risk for (fatal) ventricular arrhythmias (Wang et al., 1995; Wang et al., 1996; Makita et al., 2002; Hedley et al., 2009; Cardona et al., 2010; Yamamura et al., 2010; Lowe et al., 2012). Severe bradycardia together with an enhanced $\mathrm{I}_{\mathrm{Na} \text {,late }}$ and a long APD may also promote delayed afterdepolarization (DAD)-mediated triggered activities (Song et al., 2008; Coppini et al., 2013; Horvath et al., 2013). These triggered activities seem to heavily depend on an increased $\left[\mathrm{Ca}^{2+}\right]_{\mathrm{i}}$.

As described previously, an increased $\left[\mathrm{Na}^{+}\right]_{\mathrm{i}}$ offsets NCX, decreasing $\mathrm{Ca}^{2+}$ removal from the cytosol (Bers, 2002; Nagy et al., 2004; Despa and Bers, 2013). This elevates diastolic $\left[\mathrm{Ca}^{2+}\right]_{\mathrm{i}}$ and therefore increasing SR $\mathrm{Ca}^{2+}$ content; leading to spontaneous $\mathrm{Ca}^{2+}$ release events from the $\mathrm{Ca}^{2+}$-overloaded SR (Gyorke and Terentyev, 2008). This can generate DADs and therefore possibly triggering arrhythmias. At high heart rates this can further be aggravated by the two feedback loops involving CaMKII, as described in the previous sections, resulting in an enhanced CaMKII mediated phosphorylation of RyR2 therefore increasing the probability of spontaneous SR $\mathrm{Ca}^{2+}$ release events. It must be noted again that in vivo, there is no high heart rate without $\beta$-adrenergic stimulation. Adrenergic stimulation on one hand further activates CaMKII (Hegyi et al., 2018) but on the other hand, it also reduces or even diminishes $\left[\mathrm{Na}^{+}\right]_{\mathrm{i}}$ loading of the cells by enhancing NKP activity (Cheung et al., 2010). This makes the role of $\mathrm{I}_{\mathrm{Na} \text {, late }}$ in $\mathrm{DAD}$-mediated arrhythmias occurring at high heart rates questionable.

In the diseased heart, however, rate-dependent properties of $\mathrm{I}_{\mathrm{Na} \text {,late }}$ and $[\mathrm{Na}+] \mathrm{i}$ are quite poorly investigated. At high pacing rates, $\mathrm{I}_{\mathrm{Na} \text {,late }}$ decreases in LQT3 $\triangle \mathrm{KPQ}$ mutant cells (Nagatomo et al., 2002) and an increased $\left[\mathrm{Na}^{+}\right]_{\mathrm{i}}$ load was reported in hypertrophied feline cells (Mills et al., 2007) as well as in human cardiomyocytes from failing hearts (Pieske et al., 2002).

Pharmacologically enhanced $\mathrm{I}_{\mathrm{Na} \text {,late }}$ increases repolarization heterogeneity in intact, isolated rabbit and guinea pig hearts (Restivo et al., 2004; Milberg et al., 2005), as well as in canine left ventricular wedge preparations giving rise to TdP (Shimizu and Antzelevitch, 1999a; Shimizu and Antzelevitch, 1999b). ATX-II also induces $\mathrm{AF}$ in a wide range of experimental conditions ( $\mathrm{Lu}$ et al., 2012; Liang et al., 2016). Many gain-of-function SCN5A mutations (including LQT3) have been associated with atrial fibrillation (AF) (Benito et al., 2008). Also, in cases of chronic 
(permanent) AF, larger $\mathrm{I}_{\mathrm{Na} \text {,late }}$ was found (Sossalla et al., 2010; Poulet et al., 2015). These data suggest that enhancement of $\mathrm{I}_{\mathrm{Na} \text {, late }}$ might play a role in generating or maintaining $\mathrm{AF}$ most likely because of $\left[\mathrm{Na}^{+}\right]_{\mathrm{i}}$ overload dependent $\mathrm{Ca}^{2+}$ overload (Nattel and Dobrev, 2012).

\section{INA,LATE AS AN ANTIARRHYTHMIC THERAPEUTIC TARGET}

\section{Sodium Channel Inhibitors}

Natural products of peptide and non-peptide structure can inhibit sodium channels, although these compounds have negligible therapeutical relevance. Clinically relevant smallmolecule sodium channel inhibitors include local anesthetics, anticonvulsants, and antiarrhythmic agents such as lidocaine, carbamazepine, phenytoin, lamotrigine, and mexiletine. These small-molecule inhibitors all bind to the so-called "local anesthetic site" of sodium channels where amino acid residues are highly conserved among different $\mathrm{Na}_{\mathrm{v}}$ subtypes (de Lera Ruiz and Kraus, 2015). Because of this, the "classic" $\mathrm{Na}_{\mathrm{v}}$ blockers are not subtype specific, they inhibit all subtypes to a certain extent. Also, these compounds somewhat inhibit both $\mathrm{I}_{\mathrm{Na} \text {,early }}$ and $\mathrm{I}_{\mathrm{Na} \text {,late, }}$ usually having a higher inhibitory effect on $\mathrm{I}_{\mathrm{Na} \text {,late }}$. Therefore most $\mathrm{Na}_{\mathrm{v}}$ blockers reduce excitability and impulse propagation (parameters associated with $\mathrm{I}_{\mathrm{Na} \text {,early }}$ ) together with the plateau sodium current $\left(\mathrm{I}_{\mathrm{Na} \text {,late }}\right)$.

\section{Selective $\mathbf{I}_{\mathbf{N a} \text {,late }}$ Inhibitors}

A few sodium channel blockers differ from the "classic" inhibitors, because they inhibit $\mathrm{I}_{\mathrm{Na}}$,ate more potently than $\mathrm{I}_{\mathrm{Na}}$, early. The molecular mechanism of the preferential $\mathrm{I}_{\mathrm{Na}}$, late inhibition is still not completely understood. Even though ranolazine was used for most of the experimental and clinical studies, other selective $\mathrm{I}_{\mathrm{Na}}$, late inhibitors also exist such as lidocaine, GS-458967, GS-462808, F15845, and GS-6615 (eleclazine). The half-maximal inhibitory concentration $\left(\mathrm{IC}_{50}\right)$ values of these inhibitors for the late and the early sodium current component are summarized in Table 1. For a more

TABLE $1 \mid I C_{50}$ values of selective late sodium current inhibitors for the late and the early sodium current component.

\begin{tabular}{|c|c|c|c|}
\hline \multirow[t]{2}{*}{ Compound } & \multicolumn{2}{|r|}{$I_{50}$ for } & \multirow[t]{2}{*}{ Reference } \\
\hline & $\mathbf{I}_{\mathrm{Na} \text {,late }}$ & $I_{\mathrm{Na}, \text { early }}$ & \\
\hline Lidocaine & $29 \mu \mathrm{M}$ & $367 \mu \mathrm{M}$ & Antzelevitch et al., 2014 \\
\hline \multirow[t]{2}{*}{ Ranolazine } & $17 \mu \mathrm{M}$ & $1329 \mu \mathrm{M}$ & Belardinelli et al., 2013 \\
\hline & $6 \mu \mathrm{M}$ & $294 \mu \mathrm{M}$ & Undrovinas et al., 2006 \\
\hline \multirow[t]{2}{*}{ GS-458967 } & $333 \mathrm{nM}$ & $<15 \%$ block at $333 \mathrm{nM}$ & Koltun et al., 2016a \\
\hline & $130 \mathrm{nM}$ & $7.5 \%$ reduction at $10 \mu \mathrm{M}$ & Belardinelli et al., 2013 \\
\hline GS-462808 & $1.9 \mu \mathrm{M}$ & $10 \%$ reduction at $10 \mu \mathrm{M}$ & Koltun et al., 2016b \\
\hline GS-6615 & $0.62 \mu \mathrm{M}$ & $51 \mu \mathrm{M}$ & Zablocki et al., 2016 \\
\hline F15845 & $3.25 \mu \mathrm{M}$ & $23 \%$ reduction at $10 \mu \mathrm{M}$ & Vacher et al., 2009 \\
\hline
\end{tabular}

Where the $I C_{50}$ value is missing, inhibition percentage at a given concentration was used instead. thorough data summary on this, see Table 2 in the review of Antzelevitch et al. (2014).

For lidocaine, $\mathrm{IC}_{50}$ values of around 25 and $300 \mu \mathrm{M}$ were determined for $\mathrm{I}_{\mathrm{Na} \text {,late }}$ and $\mathrm{I}_{\mathrm{Na} \text {,early, }}$, respectively (Antzelevitch et al., 2014).

In case of ranolazine, the $\mathrm{IC}_{50}$ values are $17 \mu \mathrm{M}$ for $\mathrm{I}_{\mathrm{Na} \text {,late }}$ and $1,329 \mu \mathrm{M}$ for $\mathrm{I}_{\mathrm{Na} \text {,early }}$ in rabbit (Belardinelli et al., 2013), whereas $6 \mu \mathrm{M}$ for $\mathrm{I}_{\mathrm{Na} \text {,late }}$ (Antzelevitch et al., 2004; Undrovinas et al., 2006) and $294 \mu \mathrm{M}$ for $\mathrm{I}_{\mathrm{Na} \text {,early }}$ (Undrovinas et al., 2006) in canine ventricular myocytes.

GS-458967 was found to have an $\mathrm{IC}_{50}$ of $333 \mathrm{nM}$ for $\mathrm{I}_{\mathrm{Na} \text {,late }}$ inhibition while exhibiting smaller than $15 \%$ block of $\mathrm{I}_{\mathrm{Na} \text {,early }}$ at the same concentration at 1 and $3 \mathrm{~Hz}$ pacing frequencies (Koltun et al., 2016a) measured on $\mathrm{Na}_{\mathrm{v}} 1.5$ channels expressed in HEK-293 cells with automated patch-clamp. In rabbit ventricular cardiomyocytes,

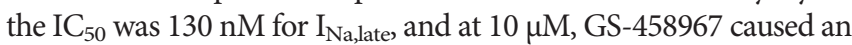

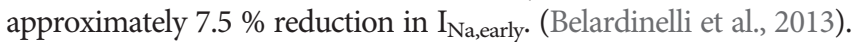
Unfortunately for the developer, GS-458967 had a high brain penetration and a profound use dependent block on all the various sodium channel isoforms, making the compound prone for possible central nervous system side effects (Koltun et al., 2016a).

GS-462808 has an $\mathrm{IC}_{50}$ of $1.9 \mu \mathrm{M}$ for $\mathrm{I}_{\mathrm{Na} \text {, late }}$ inhibition while blocking $10 \%$ of $\mathrm{I}_{\mathrm{Na} \text {,early }}$ at $10 \mu \mathrm{M}$ and it is also more cardiac isoform selective than GS-458967 blocking only $8 \%$ of the $\mathrm{Na}_{\mathrm{v}} 1.1$ peak current. The problem with GS- 462808 is that it caused liver lesions during the acute animal toxicity tests (Koltun et al., 2016b).

For GS-6615 the $\mathrm{IC}_{50}$ values of 0.62 and $51 \mu \mathrm{M}$ were reported for $\mathrm{I}_{\mathrm{Na} \text {,late }}$ and $\mathrm{I}_{\mathrm{Na} \text {,early }}$ blockade, respectively, in manual patchclamp experiments, with practically no effect on $\mathrm{Na}_{\mathrm{v}} 1.1$ channels (Zablocki et al., 2016).

F15845 has an $\mathrm{IC}_{50}$ of $3.25 \mu \mathrm{M}$ for the inhibition of veratridine-induced $\mathrm{I}_{\mathrm{Na}}$, late while blocking $23 \%$ of $\mathrm{I}_{\mathrm{Na} \text {,early }}$ at 10 $\mu \mathrm{M}$ (Vacher et al., 2009). Last experimental data about F15845 were published in 2010, where it prevented ischemia-induced arrhythmias in rats (Pignier et al., 2010). Since then no new results came out regarding this agent.

Selectivity of these specific $\mathrm{I}_{\mathrm{Na}}$,late inhibitors is usually voltagedependent, these blockers have very little effect on $\mathrm{I}_{\mathrm{Na} \text {,early }}$ at more negative (quite unphysiological, for example $-120 \mathrm{mV}$ ) holding potentials. As the holding potential gets closer to physiological resting membrane potentials, the selectivity of these compounds decrease, they start to inhibit $\mathrm{I}_{\mathrm{Na} \text {,early }}$ more. Also, most inhibitors block the sodium channels in a ratedependent ("use-dependent") fashion; the blockers are more effective at rapid than at slow heart rates. This is because most inhibitors preferentially bind to the open and/or inactivated channels rather than the closed channel. This effect is especially strong in sodium channel blockers having fast association and dissociation kinetics (Pless et al., 2011) (Vaughan-Williams class Ib agents).

In case of $1 \mu \mathrm{M}$ GS-458967 for example, $\mathrm{I}_{\mathrm{Na} \text {,early }}$ did not change in rabbit ventricular myocytes held at $-120 \mathrm{mV}$ at pacing rates of $0.1,1$, or $3 \mathrm{~Hz}$. When the holding potential was $-80 \mathrm{mV}$, however, $1 \mu \mathrm{M}$ GS-458967 reduced $\mathrm{I}_{\mathrm{Na} \text {,early }}$ by $48 \pm 7 \%, 50 \pm 7 \%$, 
and $56 \pm 8 \%$ at rates of $0.1,1$, and $3 \mathrm{~Hz}$, respectively (Belardinelli et al., 2013).

Ranolazine also inhibits sodium channels in a voltage-, and usedependent fashion, moreover this blockade is also significantly larger in atria compared to ventricles (Zygmunt et al., 2011). With $50 \mathrm{~ms}$ long depolarizing pulses and $250 \mathrm{~ms}$ diastolic intervals (at $3.33 \mathrm{~Hz}$ ), the use-dependent block by ranolazine at $-120 \mathrm{mV}$ was $21 \%$ in ventricular, versus $32 \%$ in atrial cells, whereas at $-100 \mathrm{mV}$ the block was $47 \%$ versus $56 \%$, respectively. This data suggest that the rate dependency (use-dependency) is very pronounced in case of $\mathrm{I}_{\mathrm{Na} \text {,early }}$ inhibition, but much smaller with $\mathrm{I}_{\mathrm{Na} \text {,late }}$. Therefore, based on the rate-dependent physiological (see Heart Rate and AP Duration Influences $I_{N a \text {, late }}$ ) and pharmacological characteristics of $\mathrm{I}_{\mathrm{Na}}$, early and $\mathrm{I}_{\mathrm{Na} \text {, late }}$, a quite selective inhibition of $\mathrm{I}_{\mathrm{Na} \text {, late }}$ might be achieved at slow heart rates and with long APs, but at fast rates, with short AP duration, sodium channel blockers similarly inhibit both $\mathrm{I}_{\mathrm{Na}}$, early and $\mathrm{I}_{\mathrm{Na} \text {,late. }}$

At therapeutical plasma concentrations, ranolazine inhibits other ionic currents besides $\mathrm{I}_{\mathrm{Na}}$,late. This includes $\mathrm{I}_{\mathrm{Kr}}$ (approximately $40 \%$ inhibition at $6 \mu \mathrm{M}$ ), and $\mathrm{I}_{\mathrm{Ca}, \mathrm{L}}$ (around $25 \%$ inhibition at $6 \mu \mathrm{M}$ ) (Antzelevitch et al., 2004). Consequently, inhibiting $\mathrm{I}_{\mathrm{Na} \text {,late }}$ and applying ranolazine are very far from being identical concepts. When ranolazine is used to inhibit $\mathrm{I}_{\mathrm{Na}}$,late, effects on other channels must not be forgotten. Besides the previous features, ranolazine is also a weak $\beta$-adrenergic antagonist (Letienne et al., 2001) and an inhibitor of fatty acid oxidation (Chaitman, 2006), even though this latter effect only becomes prominent at supratherapeutical plasma concentrations.

\section{Non-Cardiac Sodium Channel Inhibitors as Potential Antiarrhythmic Agents}

Riluzole blocks TTX-sensitive sodium channels preferentially, which are associated with damaged neurons (Song et al., 1997). Riluzole also directly inhibits the kainate and NMDA receptors (Debono et al., 1993) as well as potentiates $\mathrm{GABA}_{\mathrm{A}}$ receptors $(\mathrm{He}$ et al., 2002). In anaesthetized pigs, myocardial damage and arrhythmias induced by coronary occlusion has been reduced by riluzole (Weiss et al., 2013). Riluzole has also been found to be anti-ischemic and antiarrhythmic in a pig model of acute myocardial infarction. (Weiss and Saint, 2010).

Targeting $\mathrm{Na}_{\mathrm{v}} 1.8$ with specific inhibitors might provide a potential novel approach in the future in antiarrhythmic drug therapy, because recent studies have found that $\mathrm{Na}_{\mathrm{v}} 1.8$ expression is significantly up-regulated in human left ventricular hypertrophy (Ahmad et al., 2019) and HF (Dybkova et al., 2018). By using $\mathrm{Na}_{\mathrm{v}} 1.8$-specific blockers [either A-803467 (30 nM) or PF-01247324 (1 $\mu \mathrm{M})$ ] the authors managed to reduce $\mathrm{I}_{\mathrm{Na}}$, late and $\mathrm{APD}$ in these experiments. Other $\mathrm{Na}_{\mathrm{v}} 1.8$ specific inhibitors include funapide and VX-150, however these compounds have not been tested in relation to cardiac pathophysiology so far.

\section{Experimental Pathophysiology Studies}

Because of the pronounced use-dependent effect of specific $\mathrm{I}_{\mathrm{Na} \text {, late }}$ inhibitors, interpretation of experimental studies conducted on rats and mice (having resting heart rates around
$400 \mathrm{bpm}$ ) are very difficult. Therefore this review will focus on experimental data originating from larger mammalian species.

\section{Late Sodium Current Inhibition and Ventricular Arrhythmias}

As it was demonstrated in the previous sections, $\mathrm{I}_{\mathrm{Na} \text {,late }}$ has quite different characteristics under different heart rates. Therefore it is worthwhile to split the ventricular arrhythmia topic into two subtopics accordingly.

\section{Bradycardia and Long APs}

Many in vitro experimental studies have shown that at low pacing rates with prolonged APs and increased repolarization heterogeneity (LQT3 syndrome, heart failure, hypertrophic cardiomyopathy), inhibition of $\mathrm{I}_{\mathrm{Na}}$,late effectively reduces the burden of arrhythmic episodes [EADs, DADs, triggered APs, Torsade de Pointes (TdP) (Shimizu and Antzelevitch, 1997; Song et al., 2004; Coppini et al., 2013; Belardinelli et al., 2013; Rajamani et al., 2016)].

Ranolazine and GS-458967 has been shown to suppress dofetilide-induced TdP in a canine in vivo model (Antoons et al., 2010; Bossu et al., 2018).

There was one experimental study about the potential antiarrhythmic role of F15845, where it prevented ischemiainduced arrhythmias in rats (Pignier et al., 2010). However the use of a rat model makes it hard to extrapolate this study to humans.

Under the pathological conditions listed above, the fine balance between the inward and outward currents during the AP plateau is shifted toward the depolarizing inward currents, resulting in a longer AP. Therefore, theoretically, any intervention that reduces the depolarizing currents (e.g.: L-type calcium current, NCX current, $\mathrm{I}_{\mathrm{Na} \text {,late }}$ ) could be effective in bringing the repolarization closer to normal. In this setting, therefore, inhibiting $\mathrm{I}_{\mathrm{Na}}$, late will reduce the depolarization drive resulting in a significantly shorter APD and the suppression of arrhythmogenic events such as EADs, even if the magnitude of $\mathrm{I}_{\mathrm{Na} \text {, late }}$ is not increased. Under similar conditions, other interventions such as L-type calcium channel blockade (Abrahamsson et al., 1996) or potassium channel activation (Carlsson et al., 1992) can also shorten APD, reduce repolarization heterogeneity, and suppress the occurrence of arrhythmogenic events even if $\mathrm{I}_{\mathrm{Na} \text {,late }}$ is upregulated. In LQT

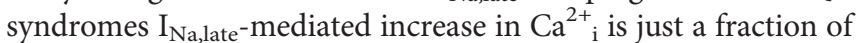
the total $\mathrm{Ca}^{2+}{ }_{\mathrm{i}}$, and even total $\mathrm{Ca}^{2+}{ }_{\mathrm{i}}$ just contributes to rather than determines the arrhythmogenic events (Carlsson et al., 1996).

\section{Tachycardia-Induced Tachyarrhythmias (VT, VF)}

$\mathrm{I}_{\mathrm{Na} \text {,late }}$ blockers seem to effectively prevent or terminate tachycardia-induced ventricular tachycardia, and ventricular fibrillation in healthy animal models in the presence of a $\beta$ adrenergic agonist (Alves Bento et al., 2015; Carneiro et al., 2015; Bacic et al., 2017).

However, inhibition of $\mathrm{I}_{\mathrm{Na} \text {, late }}$ does not likely play a crucial role here, based on the following theoretical considerations. To 
start with, in healthy ventricular tissue at high heart rates $\mathrm{I}_{\mathrm{Na} \text {,late }}$ is quite small, as it was discussed in Heart Rate and AP Duration Influences $I_{N a \text {,late }}$. Furthermore, at rapid heart rates with $\beta$ adrenergic stimulation the major arrhythmogenic mechanism is likely to be the increased L-type calcium current, the increased SR $\mathrm{Ca}^{2+}$ content, and the leaky RyR together (Merchant and Armoundas, 2012). The third but similarly important factor is that these VT/VF episodes are likely underlain by a reentry mechanism, therefore heavily depending on the fast conduction

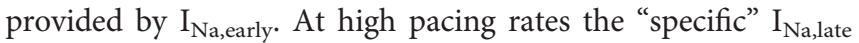
inhibitors will also block a considerable amount of $\mathrm{I}_{\mathrm{Na} \text {,early }}$ as well (see Selective $I_{N a \text {, late }}$ Inhibitors for details), and this might just be enough to break the reentry circuit (Burashnikov and Antzelevitch, 2017).

Based on the experimental data, $\mathrm{I}_{\mathrm{Na} \text {, late }}$ inhibition seems to be a valid therapeutic approach to tackle ventricular arrhythmias especially at low heart rates. These experimental studies also suggest that $\mathrm{I}_{\mathrm{Na} \text {,late }}$ inhibition mainly affects the arrhythmogenic substrate by making the repolarization less heterogenous (Carneiro et al., 2015), with only low impact on suppressing the triggers (Bossu et al., 2018).

\section{Late Sodium Current Inhibition in AF}

GS-458967 was shown to suppress isoproterenol-, and high $\mathrm{Ca}^{2+}$-induced DADs in healthy canine pulmonary-, and superior vena cava preparations (Sicouri et al., 2013). GS458967 also suppressed autonomically triggered AF in an intact porcine model (Carneiro et al., 2015). In other experimental studies, "classic" sodium channel inhibitors (eg, lidocaine, flecainide) also prevented and terminated AF (Wang et al., 1992; Comtois et al., 2008). However, these agents were used at concentrations causing a suppression of

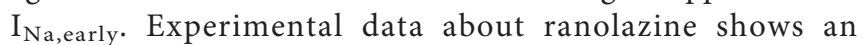
effective reduction of AF burden (AFB) only at concentrations that potently inhibit both $\mathrm{I}_{\mathrm{Na}}$,early (Burashnikov et al., 2007; Kumar et al., 2009; Burashnikov et al., 2014) and $I_{K r}$ (Burashnikov et al., 2007) Suppressing $I_{K r}$ reduces the diastolic interval between APs therefore promoting rate-dependent $\mathrm{I}_{\mathrm{Na} \text {,early }}$ inhibition.

Based on these data, specific $\mathrm{I}_{\mathrm{Na}}$,ate blockade alone is not a clear and straightforward approach in AF, except for cases when a longer atrial $\mathrm{AP}$ is the pathogenetic factor in the initiation of $\mathrm{AF}$.

\section{Clinical Studies Ranolazine}

So far, ranolazine has been used in the vast majority of clinical studies involving $\mathrm{I}_{\mathrm{Na} \text {,late }}$ blockers. When interpreting these trials, it has to be considered that ranolazine has other effects besides inhibiting $\mathrm{I}_{\mathrm{Na} \text {,late }}$. With the use of ranolazine, the first favorable results from phase 2 clinical trials were published in the 1990s (Cocco et al., 1992; Thadani et al., 1994). In 2006, following the outcome of the MARISA (Chaitman et al., 2004a), CARISA (Chaitman et al., 2004b), and ERICA (Stone et al., 2006) trials, the Food and Drug Administration approved ranolazine as an anti-anginal agent.

The effect of clinical outcome and safety of ranolazine therapy was investigated in more than 6,500 patients with non-STelevation acute coronary syndrome in the MERLIN TIMI-36 trial (Morrow et al., 2007). Although cardiovascular death or myocardial infarction has not been significantly reduced by ranolazine when compared to standard therapy; but recurrent ischemia (Morrow et al., 2007) and the incidence of arrhythmias (Scirica et al., 2007) were significantly lower with ranolazine. Treatment with ranolazine, compared to placebo, resulted in significantly lower incidences of arrhythmias. Fewer patients had episodes of ventricular tachycardia lasting more than eight beats [166 (5.3\%) versus $265(8.3 \%) ; \mathrm{p}<0.001]$, supraventricular tachycardia [1413 (44.7\%) versus $1752(55.0 \%) ; \mathrm{p}<0.001]$, or new-onset AF [55 (1.7\%) versus 75 (2.4\%); p=0.08]. Moreover, longer than $3 \mathrm{~s}$ pauses were less frequent with ranolazine [97 (3.1\%) versus $136(4.3 \%) ; \mathrm{p}=0.01]$.

In the double-blind HARMONY (ClinicalTrials.gov ID: NCT01522651) phase 2 trial (Reiffel et al., 2015), patients with paroxysmal AF and implanted pacemakers were enrolled, so that AFB could continuously be monitored over the 12 weeks of treatment period. Patients were randomized to placebo, ranolazine alone (750 $\mathrm{mg}$ twice a day-BID), dronedarone alone (225 mg BID), or ranolazine (750 mg BID) combined with dronedarone (either $150 \mathrm{mg}$ BID or $225 \mathrm{mg}$ BID). The idea behind the combination was to reduce the dose of dronedarone, and therefore the negative inotropic effect associated with dronedarone. Placebo or the drugs alone did not significantly reduce $\mathrm{AFB}$. In the combination therapies, however, ranolazine with dronedarone $225 \mathrm{mg}$ BID reduced AFB by $59 \%$ vs placebo $(\mathrm{p}=0.008)$, and ranolazine with dronedarone $150 \mathrm{mg}$ BID reduced AFB by $43 \%(\mathrm{p}=0.072)$. Also, patients tolerated both combinations well.

Into the RAFFAELLO phase 2 trial (De Ferrari et al., 2015) patients with persistent AF (7 days to 6 months) were enrolled. Two hours after successful electrical cardioversion participants were randomized to either placebo, or ranolazine $375 \mathrm{mg}, 500$ $\mathrm{mg}$, or $750 \mathrm{mg}$ BID. Patients were monitored daily by transtelephonic ECG. The primary end-point was the time to first AF recurrence. No dose of the ranolazine prolonged time to AF recurrence significantly compared to placebo. Of the 238 patients who took at least one dose of the study drug, AF recurred in $56.4 \%, 56.9 \%, 41.7 \%$, and $39.7 \%$ of patients in the placebo and ranolazine $375 \mathrm{mg} / 500 \mathrm{mg} / 750 \mathrm{mg}$ groups, respectively. The reduction in overall $\mathrm{AF}$ recurrence in the combined 500-mg and 750-mg groups was of borderline significance compared to the placebo group $(\mathrm{p}=0.053)$ and significant compared to 375-mg group ( $\mathrm{p}=0.035)$.

The RAID clinical trial (NCT01534962) (Zareba et al., 2018) investigated high-risk cardiomyopathy patients who received an implantable cardioverter-defibrillator (ICD). The subjects received either ranolazine $(1,000 \mathrm{mg} \mathrm{BID})$ or placebo. The primary endpoints were VT or VF requiring ICD shock or 
death. Among 1,012 ICD patients the ranolazine versus placebo hazard ratio was 0.84 (95\% confidence interval: 0.67 to 1.05 ; $\mathrm{p}=0.117$ ) for the primary endpoint. In the ranolazine group the risk of ICD therapies for recurrent VT or VF were significantly lower (hazard ratio: 0.70 ; $95 \%$ confidence interval: 0.51 to 0.96 ; $\mathrm{p}=0.028$ ). Other effects of ranolazine treatment however has not been significant. These included individual components of the primary endpoint, quality of life, cardiac hospitalizations, and inappropriate ICD shocks as well.

In a smaller group of participants of the RAND-CFR trial (NCT01754259) (Evaristo et al., 2018) where symptomatic diabetic patients participated with non-flow-limiting coronary artery stenosis with diffuse atherosclerosis and/or microvascular dysfunction, effect of ranolazine on T-wave heterogeneity was evaluated. At physical rest, in the ranolazine group $\mathrm{T}$-wave heterogeneity was $28 \%$ smaller (placebo: $47 \pm 6 \mu \mathrm{V}$, ranolazine: $39 \pm 5 \mu \mathrm{V}, \mathrm{p}=0.002$ ), however ranolazine did not differ from the placebo group during exercise. The trial also suggested that reduction in repolarization abnormalities seemed to be independent of alterations in myocardial blood flow.

In a meta-analysis of eight randomized clinical trials (Gong et al., 2017) Gong et al. found that ranolazine significantly reduced AF incidence in different clinical settings, such as in acute coronary syndromes, after cardiac surgery and after electrical cardioversion of $\mathrm{AF}$ (relative risk=0.67, 95\% confidence interval: 0.52-0.87, $\mathrm{p}=0.002$ ). Moreover, the combined use of ranolazine and amiodarone compared to amiodarone alone showed a 1.23-times higher conversion rate of AF (95\% confidence interval: 1.08-1.40), together with a significantly, about $10 \mathrm{~h}$ shorter conversion time.

Based on the evidence above, ranolazine may have therapeutic role in the treatment of cardiac rhythm disorders, of both atrial and ventricular origin. For stronger evidence, more phase 3 clinical investigations are necessary.

\section{Eleclazine (GS-6615)}

Besides ranolazine, until now eleclazine was the only other selective $\mathrm{I}_{\mathrm{Na} \text {, late }}$ inhibitor drug candidate that made it to phase 3 clinical trials. In the first trial (NCT02300558) eleclazine was tested for safety, tolerability, and its effect on shortening of the QT interval in LQT3 patients. The primary outcome of the study showed that after 24 weeks the mean daytime corrected QT interval was significantly, 8.5 $\mathrm{ms}$ shorter than at baseline, and there was only one patient with a serious adverse event (nephrolithiasis). The other trial (LIBERTYHCM; NCT02291237) targeted HCM patients for the effect of eleclazine on exercise capacity. In this trial, eleclazine has not been proven to be superior to placebo.

The last moment in the development of eleclazine came after results of the phase 2 TEMPO study (NCT02104583) were analyzed. In the trial, subjects with ventricular tachycardia/ ventricular fibrillation and ICD participated. Results of the study have shown that the rate of ICD shocks was higher in subjects who received eleclazine compared to the placebo arm.
Therefore in late 2016, the further development of eleclazine was terminated for all indications.

\section{CONCLUSIONS}

An increased $\mathrm{I}_{\mathrm{Na} \text {,late }}$ is present in many heart diseases. The upregulated $\mathrm{I}_{\mathrm{Na}}$,ate lengthens the cardiac $\mathrm{AP}$, increases $\left[\mathrm{Na}^{+}\right]_{\mathrm{i}}$, and causes $\mathrm{Ca}^{2+}$ overload of cardiomyocytes by offsetting the forward mode NCX. The elevated $\mathrm{Ca}^{2+}$, in turn, mainly through CaMKII, can further increase $\mathrm{I}_{\mathrm{Na} \text {,late }}$ in a vicious circle. These pathophysiological mechanisms together may result in impaired cardiac energetics and contractile dysfunction of the heart as well as cardiac arrhythmias. The prolonged AP can serve as a substrate that is prone to rhythm disorders, whereas $\mathrm{Ca}^{2+}$ overload can be the trigger. $\mathrm{I}_{\mathrm{Na} \text {,late }}$ seems to possess a pathogenetic role especially in AF and in ventricular arrhythmias occurring under bradycardic conditions.

Multitude of pathophysiology studies have drawn the consequence that selective $\mathrm{I}_{\mathrm{Na} \text {,late }}$ inhibition is a favorable antiarrhythmic tool in many experimental settings. Despite all these studies, the one and only drug on the market that selectively inhibits $\mathrm{I}_{\mathrm{Na} \text {,late }}$ is ranolazine, although it significantly affects other ionic currents as well. Ranolazine has been a safe and effective antianginal medication since 2006 based on large randomized studies. Some recent clinical evidence also proves that ranolazine shows favorable effects in AF and in ventricular arrhythmias. For stronger evidence, more phase 3 clinical investigations are necessary. Targeting $\mathrm{Na}_{\mathrm{v}} 1.8$ with specific inhibitors is also an interesting novel approach in the future of antiarrhythmic drug therapy.

\section{AUTHOR CONTRIBUTIONS}

$\mathrm{BH}$ : conception, design and drafting the manuscript $\mathrm{TH}, \mathrm{DK}$, KK: writing sections of the manuscript JM, PN, TB: conception and final review of the manuscript. All authors agreed on publishing the manuscript in the current form.

\section{FUNDING}

Funding was obtained from the National Research, Development and Innovation Fund for research projects FK-128116 and PD120794, and the Thematic Excellence Programme ED_18-12019-0028. Further funding was obtained from the GINOP2.3.2-15-2016-00040 and EFOP-3.6.2-16-2017-00006 projects, which are co-financed by the European Union and the European Regional Development Fund. Research of $\mathrm{BH}$ and DK was supported by the Ministry of Human Capacities (ÚNKP-19-4-DE-284 to BH, ÚNKP-19-3-II-DE-288 to DK). The work was also supported by the Hungarian Academy of Sciences (János Bolyai Research Scholarship to $\mathrm{BH}$ ). 


\section{REFERENCES}

Abrahamsson, C., Carlsson, L., and Duker, G. (1996). Lidocaine and nisoldipine attenuate almokalant-induced dispersion of repolarization and early afterdepolarizations in vitro. J. Cardiovasc. Electrophysiol. 7 (11), 1074-1081. doi: 10.1111/j.1540-8167.1996.tb00483.x

Ahern, G. P., Hsu, S. F., Klyachko, V. A., and Jackson, M. B. (2000). Induction of persistent sodium current by exogenous and endogenous nitric oxide. J. Biol. Chem. 275 (37), 28810-28815. doi: 10.1074/jbc.M003090200

Ahern, C. A., Zhang, J.-F., Wookalis, M. J., and Horn, R. (2005). Modulation of the Cardiac Sodium Channel NaV1.5 by Fyn, a Src Family Tyrosine Kinase. Circ. Res. 96 (9), 991-998. doi: 10.1161/01.RES.0000166324.00524.dd

Ahmad, S., Tirilomis, P., Pabel, S., Dybkova, N., Hartmann, N., Molina, C. E., et al. (2019). The functional consequences of sodium channel NaV 1.8 in human left ventricular hypertrophy. ESC Heart Fail 6 (1), 154-163. doi: 10.1002/ ehf 2.12378

Akalin, F., Tirtir, A., and Yilmaz, Y. (2003). Increased QT dispersion in epileptic children. Acta Paediatr. 92 (8), 916-920. doi: 10.1080/08035250310003550

Alekov, A. K., Rahman, M. M., Mitrovic, N., Lehmann-Horn, F., and Lerche, H. (2000). A sodium channel mutation causing epilepsy in man exhibits subtle defects in fast inactivation and activation in vitro. J. Physiol. (Lond.) 529 (3), 533-539. doi: 10.1111/j.1469-7793.2000.00533.x

Alves Bento, A. S., Bacic, D., Saran Carneiro, J., Nearing, B. D., Fuller, H., Justo, F. A., et al. (2015). Selective late INa inhibition by GS-458967 exerts parallel suppression of catecholamine-induced hemodynamically significant ventricular tachycardia and T-wave alternans in an intact porcine model. Heart Rhythm 12 (12), 2508-2514. doi: 10.1016/j.hrthm.2015.07.025

Anderson, M. E. (2005). Calmodulin kinase signaling in heart: an intriguing candidate target for therapy of myocardial dysfunction and arrhythmias. Pharmacol. Ther. 106 (1), 39-55. doi: 10.1016/j.pharmthera.2004.11.002

Antoons, G., Oros, A., Beekman, J. D., Engelen, M. A., Houtman, M. J., Belardinelli, L., et al. (2010). Late na(+) current inhibition by ranolazine reduces torsades de pointes in the chronic atrioventricular block dog model. J. Am. Coll. Cardiol. 55 (8), 801-809. doi: 10.1016/j.jacc.2009.10.033

Antzelevitch, C., Belardinelli, L., Zygmunt, A. C., Burashnikov, A., Di Diego, J. M., Fish, J. M., et al. (2004). Electrophysiological effects of ranolazine, a novel antianginal agent with antiarrhythmic properties. Circulation 110 (8), 904-910. doi: 10.1161/01.CIR.0000139333.83620.5D

Antzelevitch, C., Nesterenko, V., Shryock, J. C., Rajamani, S., Song, Y., and Belardinelli, L. (2014). The role of late I na in development of cardiac arrhythmias. Handb. Exp. Pharmacol. 221, 137-168. doi: 10.1007/978-3-642-41588-3_7

Ashpole, N. M., Herren, A. W., Ginsburg, K. S., Brogan, J. D., Johnson, D. E., Cummins, T. R, et al. (2012). Ca2+/calmodulin-dependent protein kinase II (CaMKII) regulates cardiac sodium channel NaV1.5 gating by multiple phosphorylation sites. J. Biol. Chem. 288, 1985619869. doi: $10.1074 /$ bc.M111.322537

Bacic, D., Carneiro, J. S., Bento, A. A., Nearing, B. D., Rajamani, S., Belardinelli, L., et al. (2017). Eleclazine, an inhibitor of the cardiac late sodium current, is superior to flecainide in suppressing catecholamine-induced ventricular tachycardia and T-wave alternans in an intact porcine model. Heart Rhythm. 14 (3), 448-454. doi: 10.1016/j.hrthm.2016.10.021

Banyasz, T., Fulop, L., Magyar, J., Szentandrassy, N., Varro, A., and Nanasi, P. P. (2003). Endocardial versus epicardial differences in L-type calcium current in canine ventricular myocytes studied by action potential voltage clamp. Cardiovasc. Res. 58 (1), 66-75. doi: 10.1016/s0008-6363(02)00853-2

Banyasz, T., Horvath, B., Virag, L., Barandi, L., Szentandrassy, N., Harmati, G., et al. (2009). Reverse rate dependency is an intrinsic property of canine cardiac preparations. Cardiovasc. Res. 84 (2), 237-244. doi: 10.1093/cvr/cvp213

Banyasz, T., Horvath, B., Jian, Z., Izu, L. T., and Ye, C.-I. (2012). Profile of L-type Ca2+ current and $\mathrm{Na}+/ \mathrm{Ca} 2+$ exchange current during cardiac action potential in ventricular myocytes. Heart Rhythm 9 (1), 134-142. doi: 10.1016/j.hrthm.2011.08.029

Belardinelli, L., Antzelevitch, C., and Fraser, H. (2004). Inhibition of late (sustained/ persistent) sodium current: a potential drug target to reduce intracellular sodiumdependent calcium overload and its detrimental effects on cardiomyocyte function. Eur. Heart J. Suppl. 6 (I), I3-I7. doi: 10.1093/eurheartj/6.suppl_i.i3

Belardinelli, L., Shryock, J. C., and Fraser, H. (2006). Inhibition of the late sodium current as a potential cardioprotective principle: effects of the late sodium current inhibitor ranolazine. Heart 92, 6-14. doi: 10.1136/hrt.2005.078790
Belardinelli, L., Liu, G., Smith-Maxwell, C., Wang, W. Q., El-Bizri, N., Hirakawa, R., et al. (2013). A novel, potent, and selective inhibitor of cardiac late sodium current suppresses experimental arrhythmias. J. Pharmacol. Exp. Ther. 344 (1), 23-32. doi: 10.1124/jpet.112.198887

Beltran-Alvarez, P., Pagans, S., and Brugada, R. (2011). The cardiac sodium channel is post-translationally modified by arginine methylation. J. Proteome Res. 10 (8), 3712-3719. doi: 10.1021/pr200339n

Benito, B., Brugada, R., Perich, R. M., Lizotte, E., Cinca, J., Mont, L., et al. (2008). A mutation in the sodium channel is responsible for the association of long QT syndrome and familial atrial fibrillation. Heart Rhythm 5 (10), 1434-1440. doi: $10.1016 /$ j.hrthm.2008.07.013

Bers, D. M., and Grandi, E. (2009). Calcium/Calmodulin-dependent Kinase II Regulation of Cardiac Ion Channels. J. Cardiovasc. Pharmacol. 54 (3), 180-187. doi: 10.1097/FJC.0b013e3181a25078

Bers, D. M. (2002). Cardiac excitation-contraction coupling. Nature 415 (6868), 198-205. doi: 10.1038/415198a

Bers, D. M. (2010). CaMKII Inhibition in Heart Failure Makes Jump to Human. Circ. Res. 107 (9), 1044-1046. doi: 10.1161/circresaha.110.231902

Beyder, A., Rae, J. L., Bernard, C., Strege, P. R., Sachs, F., and Farrugia, G. (2010). Mechanosensitivity of $\mathrm{Na}(\mathrm{v}) 1.5$, a voltage-sensitive sodium channel. J. Physiol. (Lond.) 588 (24), 4969-4985. doi: 10.1113/jphysiol.2010.199034

Beyder, A., Strege, P. R., Reyes, S., Bernard, C. E., Terzic, A., Makielski, J., et al. (2012). Ranolazine Decreases Mechanosensitivity of the Voltage-Gated Sodium Ion Channel $\mathrm{Na}(\mathrm{V}) 1.5$ A Novel Mechanism of Drug Action. Circulation 125 (22), 2698-U2695. doi: 10.1161/circulationaha.112.094714

Bezzina, C., Veldkamp, M. W., van den Berg, M. P., Postma, A. V., Rook, M. B., Viersma, J. W., et al. (1999). A single $\mathrm{Na}+$ channel mutation causing both longQT and Brugada syndromes. Circ. Res. 85 (12), 1206-1213. doi: 10.1161/ 01.RES.85.12.1206

Biet, M., Barajas-Martinez, H., Ton, A. T., Delabre, J. F., Morin, N., and Dumaine, R. (2012). About half of the late sodium current in cardiac myocytes from dog ventricle is due to non-cardiac-type Na+ channels. J. Mol. Cell. Cardiol. 53 (5), 593598. doi: 10.1016/j.yjmcc.2012.06.012

Bonatti, R., Silva, A. F., Batatinha, J. A., Sobrado, L. F., Machado, A. D., Varone, B. B., et al. (2014). Selective late sodium current blockade with GS-458967 markedly reduces ischemia-induced atrial and ventricular repolarization alternans and ECG heterogeneity. Heart Rhythm 11 (10), 1827-1835. doi: 10.1016/j.hrthm.2014.06.017

Bossu, A., Houtman, M. J. C., Meijborg, V. M. F., Varkevisser, R., Beekman, H. D. M. Dunnink, A., et al. (2018). Selective late sodium current inhibitor GS-458967 suppresses Torsades de Pointes by mostly affecting perpetuation but not initiation of the arrhythmia. Br. J. Pharmacol. 175 (12), 2470-2482. doi: 10.1111/bph.14217

Burashnikov, A., and Antzelevitch, C. (2008). Atrial-selective sodium channel blockers: do they exist? J. Cardiovasc. Pharmacol. 52 (2), 121-128. doi: 10.1097/ FJC.0b013e31817618eb

Burashnikov, A., and Antzelevitch, C. (2013). Role of late sodium channel current block in the management of atrial fibrillation. Cardiovasc. Drugs Ther. 27 (1), 79-89. doi: 10.1007/s10557-012-6421-1

Burashnikov, A., and Antzelevitch, C. (2017). Effectiveness of Late INa Versus Peak INa Block in the Setting of Ventricular Fibrillation. Circ. Arrhythm. Electrophysiol. 10 (3), e005111. doi: 10.1161/CIRCEP.117.005111

Burashnikov, A., Di Diego, J. M., Zygmunt, A. C., Belardinelli, L., and Antzelevitch, C. (2007). Atrium-selective sodium channel block as a strategy for suppression of atrial fibrillation: differences in sodium channel inactivation between atria and ventricles and the role of ranolazine. Circulation 116 (13), 1449-1457. doi: 10.1161/CIRCULATIONAHA.107.704890

Burashnikov, A., Di Diego, J. M., Barajas-Martinez, H., Hu, D., Cordeiro, J. M., Moise, N. S., et al. (2014). Ranolazine effectively suppresses atrial fibrillation in the setting of heart failure. Circ. Heart Fail 7 (4), 627-633. doi: 10.1161/ CIRCHEARTFAILURE.114.001129

Burnashev, N. A., Undrovinas, A. I., Fleidervish, I. A., Makielski, J. C., and Rosenshtraukh, L. V. (1991). Modulation of cardiac sodium-channel gating by lysophosphatidylcholine. J. Mol. Cell Cardiol. 23, 23-30. doi: 10.1016/00222828(91)90020-m

Cardona, K., Trenor, B., Rajamani, S., Romero, L., Ferrero, J. M., and Saiz, J. (2010). "Effects of late sodium current enhancement during LQT-related arrhythmias. A simulation study," in Conference proceedings: Annual International Conference of the IEEE Engineering in Medicine and Biology 
Society. [Buenos Aires: IEEE (Institute of Electrical and Electronics Engineers)] 2010, 3237-3240. doi: 10.1109/iembs.2010.5627184

Carlsson, L., Abrahamsson, C., Drews, L., and Duker, G. (1992). Antiarrhythmic effects of potassium channel openers in rhythm abnormalities related to delayed repolarization. Circulation 85 (4), 1491-1500. doi: 10.1161/01.cir.85.4.1491

Carlsson, L., Drews, L., and Duker, G. (1996). Rhythm anomalies related to delayed repolarization in vivo: influence of sarcolemmal Ca++ entry and intracellular Ca++ overload. J. Pharmacol. Exp. Ther. 279 (1), 231-239.

Carmeliet, E. (1999). Cardiac ionic currents and acute ischemia: From channels to arrhythmias. Physiol. Rev. 79 (3), 917-1017. doi: 10.1152/physrev.1999.79.3.917

Carmeliet, E. (2006). Action potential duration, rate of stimulation, and intracellular sodium. J. Cardiovasc. Electrophysiol. 17 Suppl 1, S2-S7. doi: $10.1111 / j .1540-8167.2006 .00378 . x$

Carneiro, J. S., Bento, A. S., Bacic, D., Nearing, B. D., Rajamani, S., Belardinelli, L., et al. (2015). The Selective Cardiac Late Sodium Current Inhibitor GS-458967 Suppresses Autonomically Triggered Atrial Fibrillation in an Intact Porcine Model. J. Cardiovasc. Electrophysiol. 26 (12), 1364-1369. doi: 10.1111/jce.12824

Catterall, W. A., Goldin, A. L., and Waxman, S. G. (2005). International Union of Pharmacology. XLVII. Nomenclature and structure-function relationships of voltage-gated sodium channels. Pharmacol. Rev. 57 (4), 397-409. doi: 10.1124/ pr.57.4.4

Chaitman, B. R., Skettino, S. L., Parker, J. O., Hanley, P., Meluzin, J., Kuch, J., et al. (2004a). Anti-ischemic effects and long-term survival during ranolazine monotherapy in patients with chronic severe angina. J. Am. Coll. Cardiol. 43 (8), 1375-1382. doi: 10.1016/j.jacc.2003.11.045

Chaitman, B. R., Pepine, C. J., Parker, J. O., Skopal, J., Chumakova, G., Kuch, J., et al. (2004b). Effects of ranolazine with atenolol, amlodipine, or diltiazem on exercise tolerance and angina frequency in patients with severe chronic angina: a randomized controlled trial. JAMA 291 (3), 309-316. doi: 10.1001/jama.291.3.309

Chaitman, B. R. (2006). Ranolazine for the treatment of chronic angina and potential use in other cardiovascular conditions. Circulation 113 (20), 24622472. doi: 10.1161/CIRCULATIONAHA.105.597500

Cheng, J., Valdivia, C. R., Vaidyanathan, R., Balijepalli, R. C., Ackerman, M. J., and Makielski, J. C. (2013). Caveolin-3 suppresses late sodium current by inhibiting nNOS-dependent S-nitrosylation of SCN5A. J. Mol. Cell Cardiol. 61, 102-110. doi: 10.1016/j.yjmcc.2013.03.013

Cheung, J. Y., Zhang, X. Q., Song, J., Gao, E., Rabinowitz, J. E., Chan, T. O., et al. (2010). Phospholemman: a novel cardiac stress protein. Clin. Transl. Sci. 3 (4), 189-196. doi: 10.1111/j.1752-8062.2010.00213.x

Clancy, C. E., Tateyama, M., Liu, H., Wehrens, X. H., and Kass, R. S. (2003). Nonequilibrium gating in cardiac $\mathrm{Na}+$ channels: an original mechanism of arrhythmia. Circulation 107 (17), 2233-2237. doi: 10.1161/01.CIR.0000069273.51375.BD

Cocco, G., Rousseau, M. F., Bouvy, T., Cheron, P., Williams, G., Detry, J. M., et al. (1992). Effects of a new metabolic modulator, ranolazine, on exercise tolerance in angina pectoris patients treated with beta-blocker or diltiazem. J. Cardiovasc. Pharmacol. 20 (1), 131-138.

Cohen, S. A., and Levitt, L. K. (1993). Partial characterization of the rH1 sodium channel protein from rat heart using subtype-specific antibodies. Circ. Res. 73 (4), 735-742. doi: 10.1161/01.res.73.4.735

Comtois, P., Sakabe, M., Vigmond, E. J., Munoz, M., Texier, A., ShiroshitaTakeshita, A., et al. (2008). Mechanisms of atrial fibrillation termination by rapidly unbinding $\mathrm{Na}+$ channel blockers: insights from mathematical models and experimental correlates. Am. J. Physiol. Heart Circ. Physiol. 295 (4), H1489-H1504. doi: 10.1152/ajpheart.01054.2007

Coppini, R., Ferrantini, C., Yao, L., Fan, P., Del Lungo, M., Stillitano, F., et al. (2013). Late sodium current inhibition reverses electromechanical dysfunction in human hypertrophic cardiomyopathy. Circulation 127 (5), 575-584. doi: 10.1161/circulationaha.112.134932

Coraboeuf, E., Deroubaix, E., and Coulombe, A. (1979). Effect of tetrodotoxin on action potentials of the conducting system in the dog heart. Am. J. Physiol. 236 (4), H561-H567. doi: 10.1152/ajpheart.1979.236.4.H561

Cortada, E., and Brugada, R. (2019). Verges M. N-Glycosylation of the voltagegated sodium channel beta2 subunit is required for efficient trafficking of NaV1.5/beta2 to the plasma membrane. J. Biol. Chem. 294 (44), 16123-16140. doi: $10.1074 /$ jbc.RA119.007903

De Ferrari, G. M., Maier, L. S., Mont, L., Schwartz, P. J., Simonis, G., Leschke, M., et al. (2015). Ranolazine in the treatment of atrial fibrillation: Results of the dose-ranging RAFFAELLO (Ranolazine in Atrial Fibrillation Following An
ELectricaL CardiOversion) study. Heart Rhythm 12 (5), 872-878. doi: 10.1016/ j.hrthm.2015.01.021

de Lera Ruiz, M., and Kraus, R. L. (2015). Voltage-Gated Sodium Channels: Structure, Function, Pharmacology, and Clinical Indications. J. Med. Chem. 58 (18), 7093-7118. doi: 10.1021/jm501981g

Debono, M. W., Le Guern, J., Canton, T., Doble, A., and Pradier, L. (1993). Inhibition by riluzole of electrophysiological responses mediated by rat kainate and NMDA receptors expressed in Xenopus oocytes. Eur. J. Pharmacol. 235 (23), 283-289. doi: 10.1016/0014-2999(93)90147-a

Despa, S., and Bers, D. M. (2013). Na+ transport in the normal and failing heart Remember the balance. J. Mol. Cell Cardiol. 61, 2-10. doi: 10.1016/ j.yjmcc.2013.04.011

Despa, S., Islam, M. A., Weber, C. R., Pogwizd, S. M., and Bers, D. M. (2002). Intracellular $\mathrm{Na}+$ Concentration Is Elevated in Heart Failure But Na/K Pump Function Is Unchanged. Circulation 105 (21), 2543-2548. doi: 10.1161/ 01.cir.0000016701.85760.97

Dybkova, N., Ahmad, S., Pabel, S., Tirilomis, P., Hartmann, N., Fischer, T. H., et al. (2018). Differential regulation of sodium channels as a novel proarrhythmic mechanism in the human failing heart. Cardiovasc. Res. 114 (13), 1728-1737. doi: $10.1093 / \mathrm{cvr} / \mathrm{cvy} 152$

El-Sherif, N., Turitto, G., and Boutjdir, M. (2019). Acquired Long QT Syndrome and Electrophysiology of Torsade de Pointes. Arrhythm. Electrophysiol. Rev. 8 (2), 122-130. doi: 10.15420/aer.2019.8.3

Erickson, J. R., Joiner, M. L. A., Guan, X., Kutschke, W., Yang, J. Y., Oddis, C. V., et al. (2008). A dynamic pathway for calcium-independent activation of CaMKII by methionine oxidation. Cell 133 (3), 462-474. doi: 10.1016/ j.cell.2008.02.048

Evaristo, E., Stocco, F. G., Shah, N. R., Cheezum, M. K., Hainer, J., Foster, C., et al. (2018). Ranolazine reduces repolarization heterogeneity in symptomatic patients with diabetes and non-flow-limiting coronary artery stenosis. Ann. Noninvas. Electrocardiol. 23 (1), el2480. doi: 10.1111/anec.12480

Fujioka, Y., Hiroe, K., and Matsuoka, S. (2000). Regulation kinetics of Na+-Ca2+ exchange current in guinea-pig ventricular myocytes. J. Physiol. (Lond.) 529 (3), 611-624. doi: 10.1111/j.1469-7793.2000.00611.x

Fulop, L., Banyasz, T., Magyar, J., Szentandrassy, N., Varro, A., and Nanasi, P. P. (2004). Reopening of L-type calcium channels in human ventricular myocytes during applied epicardial action potentials. Acta Physiol. Scand. 180 (1), 39-47. doi: 10.1046/j.0001-6772.2003.01223.x

Gellens, M. E., George, A. L., Chen, L. Q., Chahine, M., Horn, R., Barchi, R. L., et al. (1992). Primary structure and functional expression of the human cardiac tetrodotoxin-insensitive voltage-dependent sodium-channel. Proc. Natl. Acad. Sci. U. S. A. 89 (2), 554-558. doi: 10.1073/pnas.89.2.554

Ginsburg, K. S., Weber, C. R., and Bers, D. M. (2013). Cardiac Na+Ca2 +exchanger: dynamics of $\mathrm{Ca} 2+-$ dependent activation and deactivation in intact myocytes. J. Physiol. (Lond.) 591 (8), 2067-2086. doi: 10.1113/ jphysiol.2013.252080

Gong, M., Zhang, Z., Fragakis, N., Korantzopoulos, P., Letsas, K. P., Li, G., et al. (2017). Role of ranolazine in the prevention and treatment of atrial fibrillation: A meta-analysis of randomized clinical trials. Heart Rhythm 14 (1), 3-11. doi: 10.1016/j.hrthm.2016.10.008

Grandi, E., and Herren, A. W. (2014). CaMKII-dependent regulation of cardiac Na homeostasis. Front. Pharmacol. 5, 41. doi: 10.3389/fphar.2014.00041

Guo, D., Young, L., Wu, Y., Belardinelli, L., Kowey, P. R., and Yan, G.-X. (2010). Increased late sodium current in left atrial myocytes of rabbits with left ventricular hypertrophy: its role in the genesis of atrial arrhythmias. Am. J. Physiol.-Heart Circ. Physiol. 298 (5), H1375-H1381. doi: 10.1152/ajpheart.01145.2009

Gyorke, S., and Terentyev, D. (2008). Modulation of ryanodine receptor by luminal calcium and accessory proteins in health and cardiac disease. Cardiovasc. Res. 77 (2), 245-255. doi: 10.1093/cvr/cvm038

Hallaq, H., Wang, D. W., Kunic, J. D., George, A. L.Jr., Wells, K. S., and Murray, K. T. (2012). Activation of protein kinase $C$ alters the intracellular distribution and mobility of cardiac Na+ channels. Am. J. Physiol. Heart Circulatory Physiol. 302 (3), H782-H789. doi: 10.1152/ajpheart.00817.2010

Harnmarstrom, A. K. M., and Gage, P. W. (2002). Hypoxia and persistent sodium current. Eur. Biophys. J. Biophys. Lett. 31 (5), 323-330. doi: 10.1007/s00249002-0218-2

Haufe, V., Cordeiro, J. M., Zimmer, T., Wu, Y. S., Schiccitano, S., Benndorf, K., et al. (2005). Contribution of neuronal sodium channels to the cardiac fast 
sodium current I-Na is greater in dog heart Purkinje fibers than in ventricles. Cardiovasc. Res. 65 (1), 117-127. doi: 10.1016/j.cardiores.2004.08.017

He, Y., Benz, A., Fu, T., Wang, M., Covey, D. F., Zorumski, C. F., et al. (2002). Neuroprotective agent riluzole potentiates postsynaptic GABA(A) receptor function. Neuropharmacology 42 (2), 199-209. doi: 10.1016/s0028-3908(01)00175-7

Hedley, P. L., Jorgensen, P., Schlamowitz, S., Wangari, R., Moolman-Smook, J., Brink, P. A., et al. (2009). The Genetic Basis of Long QT and Short QT Syndromes: A Mutation Update. Hum. Mutat. 30 (11), 1486-1511. doi: 10.1002/humu.21106

Hegyi, B., Banyasz, T., Izu, L. T., Belardinelli, L., Bers, D. M., and Chen-Izu, Y. (2018). beta-adrenergic regulation of late $\mathrm{Na}(+)$ current during cardiac action potential is mediated by both PKA and CaMKII. J. Mol. Cell. Cardiol. 123, 168179. doi: 10.1016/j.yjmcc.2018.09.006

Horvath, B., Magyar, J., Szentandrassy, N., Birinyi, P., Nanasi, P. P., and Banyasz, T. (2006). Contribution of I-Ks to ventricular repolarization in canine myocytes. Pflug. Arch. Eur. J. Physiol. 452 (6), 698-706. doi: 10.1007/s00424-006-0077-2

Horvath, B., Banyasz, T., Jian, Z., Hegyi, B., Kistamas, K., Nanasi, P. P., et al. (2013). Dynamics of the late $\mathrm{Na}+$ current during cardiac action potential and its contribution to afterdepolarizations. J. Mol. Cell Cardiol. 64, 59-68. doi: 10.1016/j.yjmcc.2013.08.010

Horvath, B., Hezso, T., Szentandrassy, N., Kistamas, K., Arpadffy-Lovas, T., Varga, R., et al. (2020). Late sodium current in human, canine and guinea pig ventricular myocardium. J. Mol. Cell. Cardiol. 139, 14-23. doi: 10.1016/ j.yjmcc.2019.12.015

Hoyer, K., Song, Y. J., Wang, D. S., Phan, D., Balschi, J., Ingwall, J. S., et al. (2011). Reducing the Late Sodium Current Improves Cardiac Function during Sodium Pump Inhibition by Ouabain. J. Pharmacol. Exp. Ther. 337 (2), 513-523. doi: 10.1124/jpet.110.176776

Huang, B., El-Sherif, T., Gidh-Jain, M., Qin, D., and El-Sherif, N. (2001). Alterations of sodium channel kinetics and gene expression in the postinfarction remodeled myocardium. J. Cardiovasc. Electrophysiol. 12 (2), 218-225. doi: 10.1046/j.1540-8167.2001.00218.x

Huang, X., Du, Y., Yang, P., Lin, S., Xi, Y., Yang, Z., et al. (2015). Age-dependent alterations of voltage-gated $\mathrm{Na}+$ channel isoforms in rat sinoatrial node. Mech. Ageing Dev. 152, 80-90. doi: 10.1016/j.mad.2015.10.003

Janvier, N. C., and Boyett, M. R. (1996). The role of Na-Ca exchange current in the cardiac action potential. Cardiovasc. Res. 32 (1), 69-84. doi: 10.1016/s00086363(96)00017-x

Jian, Z., Han, H., Zhang, T., Puglisi, J., Izu, L. T., Shaw, J. A., et al. (2014). Mechanochemotransduction during cardiomyocyte contraction is mediated by localized nitric oxide signaling. Sci. Signal. 7 (317), ra27. doi: 10.1126/ scisignal.2005046

Jones, D. K., Peters, C. H., Tolhurst, S. A., Claydon, T. W., and Ruben, P. C. (2011). Extracellular Proton Modulation of the Cardiac Voltage-Gated Sodium Channel, Na(v)1.5. Biophys. J. 101 (9), 2147-2156. doi: 10.1016/j.bpj.2011.08.056

Jones, D. K., Peters, C. H., Allard, C. R., Claydon, T. W., and Ruben, P. C. (2013a). Proton Sensors in the Pore Domain of the Cardiac Voltage-gated Sodium Channel. J. Biol. Chem. 288 (7), 4782-4791. doi: 10.1074/jbc.M112.434266

Jones, D. K., Claydon, T. W., and Ruben, P. C. (2013b). Extracellular Protons Inhibit Charge Immobilization in the Cardiac Voltage-Gated Sodium Channel. Biophys. J. 105 (1), 101-107. doi: 10.1016/j.bpj.2013.04.022

Ju, Y. K., Saint, D. A., and Gage, P. W. (1996). Hypoxia increases persistent sodium current in rat ventricular myocytes. J. Physiol. (Lond.) 497 (2), 337-347. doi: 10.1113/jphysiol.1996.sp021772

Justo, F., Fuller, H., Nearing, B. D., Rajamani, S., Belardinelli, L., and Verrier, R. L. (2016). Inhibition of the cardiac late sodium current with eleclazine protects against ischemia-induced vulnerability to atrial fibrillation and reduces atrial and ventricular repolarization abnormalities in the absence and presence of concurrent adrenergic stimulation. Heart Rhythm 13 (9), 1860-1867. doi: $10.1016 /$ j.hrthm.2016.06.020

Kapplinger, J. D., Tester, D. J., Alders, M., Benito, B., Berthet, M., Brugada, J., et al. (2010). An international compendium of mutations in the SCN5A-encoded cardiac sodium channel in patients referred for Brugada syndrome genetic testing. Heart Rhythm 7 (1), 33-46. doi: 10.1016/j.hrthm.2009.09.069

Kim, J., Ghosh, S., Liu, H. J., Tateyama, M., Kass, R. S., and Pitt, G. S. (2004). Calmodulin mediates Ca2+ sensitivity of sodium channels. J. Biol. Chem. 279 (43), 45004-45012. doi: 10.1074/jbc.M407286200
Kiyosue, T., and Arita, M. (1989). Late sodium current and its contribution to action potential configuration in guinea pig ventricular myocytes. Circ. Res. 64 (2), 389-397. doi: 10.1161/01.res.64.2.389

Koltun, D. O., Parkhill, E. Q., Elzein, E., Kobayashi, T., Notte, G. T., Kalla, R., et al. (2016a). Discovery of triazolopyridine GS-458967, a late sodium current inhibitor (Late INai) of the cardiac NaV 1.5 channel with improved efficacy and potency relative to ranolazine. Bioorg. Med. Chem. Lett. 26 (13), 32023206. doi: 10.1016/j.bmcl.2016.03.101

Koltun, D. O., Parkhill, E. Q., Elzein, E., Kobayashi, T., Jiang, R. H., Li, X., et al. (2016b). Discovery of triazolopyridinone GS-462808, a late sodium current inhibitor (Late INai) of the cardiac Nav1.5 channel with improved efficacy and potency relative to ranolazine. Bioorg. Med. Chem. Lett. 26 (13), 3207-3211. doi: 10.1016/j.bmcl.2016.03.096

Komajda, M., Frank, R., Vedel, J., Fontaine, G., Petitot, J. C., and Grosgogeat, Y. (1980). Intracardiac conduction defects in dystrophia myotonica - electrophysiological study of 12 cases. Br. Heart J. 43 (3), 315-320. doi: 10.1136/ hrt.43.3.315

Kumar, K., Nearing, B. D., Carvas, M., Nascimento, B. C., Acar, M., Belardinelli, L., et al. (2009). Ranolazine exerts potent effects on atrial electrical properties and abbreviates atrial fibrillation duration in the intact porcine heart. J. Cardiovasc. Electrophysiol. 20 (7), 796-802. doi: 10.1111/j.1540-8167.2009.01437.x

Lei, M., Jones, S. A., Liu, J., Lancaster, M. K., Fung, S. S., Dobrzynski, H., et al. (2004). Requirement of neuronal- and cardiac-type sodium channels for murine sinoatrial node pacemaking. J. Physiol. 559 (Pt 3), 835-848. doi: 10.1113/jphysiol.2004.068643

Letienne, R., Vie, B., Puech, A., Vieu, S., Le Grand, B., and John, G. W. (2001). Evidence that ranolazine behaves as a weak beta1- and beta2-adrenoceptor antagonist in the rat [correction of cat] cardiovascular system. Naunyn-Schmiedeberg's Arch. Pharmacol. 363 (4), 464-471. doi: 10.1007/s002100000378

Li, G. R., Lau, C. P., and Shrier, A. (2002). Heterogeneity of sodium current in atrial vs epicardial ventricular myocytes of adult guinea pig hearts. J. Mol. Cell. Cardiol. 34 (9), 1185-1194. doi: 10.1006/jmcc.2002.2053

Li, W., Yu, Y., Hou, J. W., Zhou, Z. W., Guo, K., Zhang, P. P., et al. (2017). Larger rate dependence of late sodium current in cardiac Purkinje cells: A potential link to arrhythmogenesis. Heart Rhythm 14 (3), 422-431. doi: 10.1016/ j.hrthm.2016.11.036

Liang, F., Fan, P., Jia, J., Yang, S., Jiang, Z., Karpinski, S., et al. (2016). Inhibitions of late INa and CaMKII act synergistically to prevent ATX-II-induced atrial fibrillation in isolated rat right atria. J. Mol. Cell. Cardiol. 94, 122-130. doi: 10.1016/j.yjmcc.2016.04.001

Linz, K. W., and Meyer, R. (1998). Control of L-type calcium current during the action potential of guinea-pig ventricular myocytes. J. Physiol. (Lond.) 513 (2), 425-442. doi: 10.1111/j.1469-7793.1998.425bb.x

Linz, K. W., and Meyer, R. (2000). Profile and kinetics of L-type calcium current during the cardiac ventricular action potential compared in guinea-pigs, rats and rabbits. Pflug. Arch.-Eur. J. Physiol. 439 (5), 588-599. doi: 10.1007/ s004240050982

Liu, T., and O'Rourke, B. (2008). Enhancing Mitochondrial Ca2+ Uptake in Myocytes From Failing Hearts Restores Energy Supply and Demand Matching. Circ. Res. 103 (3), 279-288. doi: 10.1161/circresaha.108.175919

Liu, H., Sun, H. Y., Lau, C. P., and Li, G. R. (2007). Regulation of voltage-gated cardiac sodium current by epidermal growth factor receptor kinase in guinea pig ventricular myocytes. J. Mol. Cell Cardiol. 42 (4), 760-768. doi: 10.1016/ j.yjmcc.2006.10.013

Liu, M., Shi, G., Yang, K. C., Gu, L., Kanthasamy, A. G., Anantharam, V., et al. (2017). Role of protein kinase $\mathrm{C}$ in metabolic regulation of the cardiac $\mathrm{Na}(+)$ channel. Heart Rhythm 14 (3), 440-447. doi: 10.1016/j.hrthm.2016.12.026

Locati, E. T., Bagliani, G., Cecchi, F., Johny, H., Lunati, M., and Pappone, C. (2019). Arrhythmias due to Inherited and Acquired Abnormalities of Ventricular Repolarization. Card. Electrophysiol. Clin. 11 (2), 345-362. doi: 10.1016/j.ccep.2019.02.009

Louch, W. E., Hougen, K., Mørk, H. K., Swift, F., Aronsen, J. M., Sjaastad, I., et al. (2010). Sodium accumulation promotes diastolic dysfunction in end-stage heart failure following Serca2 knockout. J. Physiol. 588 (3), 465-478. doi: $10.1113 /$ jphysiol.2009.183517

Lowe, J. S., Stroud, D. M., Yang, T., Hall, L., Atack, T. C., and Roden, D. M. (2012). Increased late sodium current contributes to long QT-related arrhythmia 
susceptibility in female mice. Cardiovasc. Res. 95 (3), 300-307. doi: 10.1093/ $\mathrm{cvr} / \mathrm{cvs} 160$

Lu, Y. Y., Cheng, C. C., Chen, Y. C., Chen, S. A., and Chen, Y. J. (2012). ATX-IIinduced pulmonary vein arrhythmogenesis related to atrial fibrillation and long QT syndrome. Eur. J. Clin. Invest. 42 (8), 823-831. doi: 10.1111/j.13652362.2012.02655.x

Luo, A., Ma, J., Song, Y., Qian, C., Wu, Y., Zhang, P., et al. (2014). Larger late sodium current density as well as greater sensitivities to ATX II and ranolazine in rabbit left atrial than left ventricular myocytes. Am. J. Physiol. Heart Circ. Physiol. 306 (3), H455-H461. doi: 10.1152/ajpheart.00727.2013

Ma, J. H., Luo, A. T., Wu, L., Wan, W., Zhang, P. H., Ren, Z. Q., et al. (2012). Calmodulin kinase II and protein kinase $\mathrm{C}$ mediate the effect of increased intracellular calcium to augment late sodium current in rabbit ventricular myocytes. Am. J. Physiol. Cell Physiol. 302 (8), C1141-C1151. doi: 10.1152/ ajpcell.00374.2011

Magyar, J., Kiper, C. E., Dumaine, R., Burgess, D. E., Banyasz, T., and Satin, J. (2004). Divergent action potential morphologies reveal nonequilibrium properties of human cardiac Na channels. Cardiovasc. Res. 64 (3), 477-487. doi: 10.1016/j.cardiores.2004.07.014

Maier, L. S., and Sossalla, S. (2013). The late Na current as a therapeutic target: Where are we? J. Mol. Cell Cardiol. 61, 44-50. doi: 10.1016/j.yjmcc.2013.03.001

Maier, S. K., Westenbroek, R. E., Schenkman, K. A., Feigl, E. O., Scheuer, T., and Catterall, W. A. (2002). An unexpected role for brain-type sodium channels in coupling of cell surface depolarization to contraction in the heart. Proc. Natl. Acad. Sci. United States America 99 (6), 4073-4078. doi: 10.1073/ pnas.261705699

Maier, S. K. G., Westenbroek, R. E., Yamanushi, T. T., Dobrzynski, H., Boyett, M. R., Catterall, W. A., et al. (2003). An unexpected requirement for brain-type sodium channels for control of heart rate in the mouse sinoatrial node. Proc. Natl. Acad. Sci. 100 (6), 3507-3512. doi: 10.1073/pnas.2627986100

Maier, L. S. (2011). CaMKII regulation of voltage-gated sodium channels and cell excitability. Heart Rhythm 8 (3), 474-477. doi: 10.1016/j.hrthm.2010.09.080

Makielski, J. C., and Farley, A. L. (2006). $\mathrm{Na}(+)$ current in human ventricle: implications for sodium loading and homeostasis. J. Cardiovasc. Electrophysiol. 17 (Suppl 1), S15-S20. doi: 10.1111/j.1540-8167.2006.00380.x

Makita, N., Horie, M., Nakamura, T., Ai, T., Sasaki, K., Yokoi, H., et al. (2002). Druginduced Long-QT syndrome associated with a subclinical SCN5A mutation. Circulation 106 (10), 1269-1274. doi: 10.1161/01.cir.0000027139.42087.b6

Malhotra, J. D., Chen, C. L., Rivolta, I., Abriel, H., Malhotra, R., Mattei, L. N., et al. (2001). Characterization of sodium channel alpha- and beta-subunits in rat and mouse cardiac myocytes. Circulation 103 (9), 1303-1310. doi: 10.1161/ 01.CIR.103.9.1303

Maltsev, V. A., and Undrovinas, A. (2008). Late sodium current in failing heart: friend or foe? Prog. Biophys. Mol. Biol. 96 (1-3), 421-451. doi: 10.1016/ j.pbiomolbio.2007.07.010

Maltsev, V. A., Sabbah, H. N., Higgins, R. S., Silverman, N., Lesch, M., and Undrovinas, A. I. (1998). Novel, ultraslow inactivating sodium current in human ventricular cardiomyocytes. Circulation 98 (23), 2545-2552. doi: 10.1161/01.CIR.98.23.2545

Maltsev, V. A., Silverman, N., Sabbah, H. N., and Undrovinas, A. I. (2007). Chronic heart failure slows late sodium current in human and canine ventricular myocytes: Implications for repolarization variability. Eur. J. Heart Fail. 9 (3), 219-227. doi: 10.1016/j.jheart.2006.08.007

Maltsev, V. A., Reznikov, V., Undrovinas, N. A., Sabbah, H. N., and Undrovinas, A. (2008). Modulation of late sodium current by $\mathrm{Ca} 2+$, calmodulin, and CaMKII in normal and failing dog cardiomyocytes: similarities and differences. Am. J. Physiol. Heart Circulatory Physiol. 294 (4), H1597-H1608. doi: 10.1152/ajpheart.00484.2007

Maltsev, V. A., Kyle, J. W., and Undrovinas, A. (2009). Late $\mathrm{Na}(+)$ current produced by human cardiac $\mathrm{Na}(+)$ channel isoform $\mathrm{Na}(\mathrm{v}) 1.5$ is modulated by its beta(1) subunit. J. Physiol. Sci. 59 (3), 217-225. doi: 10.1007/s12576-009-0029-7

Maltsev, V. A. (2006). Undrovinas AI. A multi-modal composition of the late $\mathrm{Na}+$ current in human ventricular cardiomyocytes. Cardiovasc. Res. 69 (1), 116127. doi: $10.1016 /$ j.cardiores.2005.08.015

Merchant, F. M., and Armoundas, A. A. (2012). Role of substrate and triggers in the genesis of cardiac alternans, from the myocyte to the whole heart: implications for therapy. Circulation 125 (3), 539-549. doi: 10.1161/ CIRCULATIONAHA.111.033563
Mercier, A., Clement, R., Harnois, T., Bourmeyster, N., Bois, P., and Chatelier, A. (2015). Nav1.5 channels can reach the plasma membrane through distinct Nglycosylation states. Biochim. Biophys. Acta 1850 (6), 1215-1223. doi: 10.1016/ j.bbagen.2015.02.009

Milberg, P., Reinsch, N., Wasmer, K., Monnig, G., Stypmann, J., Osada, N., et al. (2005). Transmural dispersion of repolarization as a key factor of arrhythmogenicity in a novel intact heart model of LQT3. Cardiovasc. Res. 65 (2), 397-404. doi: 10.1016/j.cardiores.2004.10.016

Mills, G. D., Harris, D. M., Chen, X., and Houser, S. R. (2007). Intracellular sodium determines frequency-dependent alterations in contractility in hypertrophied feline ventricular myocytes. Am. J. Physiol. Heart Circ. Physiol. 292 (2), H1129H1138. doi: 10.1152/ajpheart.00375.2006

Mitsuiye, T., and Noma, A. (2002). Inactivation of cardiac Na+ channel simply through open states as revealed by single-channel analysis in guinea pig ventricular myocytes. Jpn. J. Physiol. 52 (5), 457-469. doi: 10.2170/jjphysiol.52.457

Morita, N., Lee, J. H., Xie, Y., Sovari, A., Qu, Z., Weiss, J. N., et al. (2011). Suppression of re-entrant and multifocal ventricular fibrillation by the late sodium current blocker ranolazine. J. Am. Coll. Cardiol. 57 (3), 366-375. doi: 10.1016/j.jacc.2010.07.045

Morrow, D. A., Scirica, B. M., Karwatowska-Prokopczuk, E., Murphy, S. A., Budaj, A., Varshavsky, S., et al. (2007). Effects of ranolazine on recurrent cardiovascular events in patients with non-ST-elevation acute coronary syndromes: the MERLIN-TIMI 36 randomized trial. JAMA 297 (16), 1775-1783. doi: 10.1001/jama.297.16.1775

Murphy, L., Renodin, D., Antzelevitch, C., Di Diego, J. M., and Cordeiro, J. M. (2011). Extracellular proton depression of peak and late $\mathrm{Na}$ current in the canine left ventricle. Am. J. Physiol. Heart Circ. Physiol. 301 (3), H936-H944. doi: 10.1152/ajpheart.00204.2011

Nagatomo, T., January, C. T., Ye, B., Abe, H., Nakashima, Y., and Makielski, J. C. (2002). Rate-dependent QT shortening mechanism for the LQT3 deltaKPQ mutant. Cardiovasc. Res. 54 (3), 624-629. doi: 10.1016/s0008-6363(02)00265-1

Nagy, Z. A., Virag, L., Toth, A., Biliczki, P., Acsai, K., Banyasz, T., et al. (2004). Selective inhibition of sodium-calcium exchanger by SEA-0400 decreases early and delayed afterdepolarization in canine heart. Br. J. Pharmacol. 143 (7), 827831. doi: $10.1038 /$ sj.bjp. 0706026

Nattel, S., and Dobrev, D. (2012). The multidimensional role of calcium in atrial fibrillation pathophysiology: mechanistic insights and therapeutic opportunities. Eur. Heart J. 33 (15), 1870-1877. doi: 10.1093/eurheartj/ehs079

Ninkovic, V. M., Ninkovic, S. M., Miloradovic, V., Stanojevic, D., Babic, M., Giga, V., et al. (2016). Prevalence and risk factors for prolonged QT interval and QT dispersion in patients with type 2 diabetes. Acta Diabetol. 53 (5), 737-744. doi: 10.1007/s00592-016-0864-y

Pereon, Y., Lande, G., Demolombe, S., Tich, S. N. T., Sternberg, D., Le Marec, H., et al. (2003). Paramyotonia congenita with an SCN4A mutation affecting cardiac repolarization. Neurology 60 (2), 340-342. doi: 10.1212/01.WNL.0000042093.96309.5A

Persson, F., Andersson, B., Duker, G., Jacobson, I., and Carlsson, L. (2007). Functional effects of the late sodium current inhibition by AZD7009 and lidocaine in rabbit isolated atrial and ventricular tissue and Purkinje fibre. Eur. J. Pharmacol. 558 (1-3), 133-143. doi: 10.1016/j.ejphar.2006.11.040

Pieske, B., Maier, L. S., Piacentino, V., Weisser, J., Hasenfuss, G., and Houser, S. (2002). Rate Dependence of $[\mathrm{Na}+] \mathrm{i}$ and Contractility in Nonfailing and Failing Human Myocardium. Circulation 106 (4), 447-453. doi: 10.1161/01.cir.0000023042.50192.f4

Pignier, C., Revenaz, C., Rauly-Lestienne, I., Cussac, D., Delhon, A., Gardette, J., et al. (2007). Direct protective effects of poly-unsaturated fatty acids, DHA and EPA, against activation of cardiac late sodium current. Basic Res. Cardiol. 102 (6), 553-564. doi: 10.1007/s00395-007-0676-X

Pignier, C., Rougier, J. S., Vie, B., Culie, C., Verscheure, Y., Vacher, B., et al. (2010). Selective inhibition of persistent sodium current by F 15845 prevents ischaemia-induced arrhythmias. Br. J. Pharmacol. 161 (1), 79-91. doi: 10.1111/j.1476-5381.2010.00884.x

Pless, S. A., Galpin, J. D., Frankel, A., and Ahern, C. A. (2011). Molecular basis for class Ib anti-arrhythmic inhibition of cardiac sodium channels. Nat. Commun. 2, 351. doi: 10.1038/ncomms1351

Poulet, C., Wettwer, E., Grunnet, M., Jespersen, T., Fabritz, L., Matschke, K., et al. (2015). Late Sodium Current in Human Atrial Cardiomyocytes from Patients in Sinus Rhythm and Atrial Fibrillation. PloS One 10 (6), e0131432. doi: 10.1371/journal.pone.0131432

Pourrier, M., Williams, S., McAfee, D., Belardinelli, L., and Fedida, D. (2014). CrossTalk proposal: The late sodium current is an important player in the 
development of diastolic heart failure (heart failure with a preserved ejection fraction). J. Physiol. 592 (Pt 3), 411-414. doi: 10.1113/jphysiol.2013.262261

Rajamani, S., Liu, G., El-Bizri, N., Guo, D., Li, C., Chen, X. L., et al. (2016). The novel late $\mathrm{Na}(+)$ current inhibitor, GS-6615 (eleclazine) and its antiarrhythmic effects in rabbit isolated heart preparations. Br. J. Pharmacol. 173 (21), 3088-3098. doi: 10.1111/bph.13563

Ravens, U., Wettwer, E., and Hala, O. (2004). Pharmacological modulation of ion channels and transporters. Cell Calcium 35 (6), 575-582. doi: 10.1016/ j.ceca.2004.01.011

Reiffel, J. A., Camm, A. J., Belardinelli, L., Zeng, D., Karwatowska-Prokopczuk, E., Olmsted, A., et al. (2015). The HARMONY Trial: Combined Ranolazine and Dronedarone in the Management of Paroxysmal Atrial Fibrillation: Mechanistic and Therapeutic Synergism. Circ. Arrhythm. Electrophysiol. 8 (5), 1048-1056. doi: 10.1161/CIRCEP.115.002856

Restivo, M., Caref, E. B., Kozhevnikov, D. O., and El-Sherif, N. (2004). Spatial dispersion of repolarization is a key factor in the arrhythmogenicity of long QT syndrome. J. Cardiovasc. Electrophysiol. 15 (3), 323-331. doi: 10.1046/j.15408167.2004.03493.x

Rivera-Fernandez, R., Arias-Verdu, M. D., Garcia-Paredes, T., DelgadoRodriguez, M., Arboleda-Sanchez, J. A., Aguilar-Alonso, E., et al. (2016). Prolonged QT interval in ST-elevation myocardial infarction and mortality: new prognostic scale with QT, Killip and age. J. Cardiovasc. Med. (Hagerstown) 17 (1), 11-19. doi: 10.2459/JCM.0000000000000015

Ruan, Y., Liu, N., and Priori, S. G. (2009). Sodium channel mutations and arrhythmias. Nat. Rev. Cardiol. 6 (5), 337-348. doi: 10.1038/nrcardio.2009.44

Sarhan, M. F., and Van Petegem, F. (2009). Ahern CA. A Double Tyrosine Motif in the Cardiac Sodium Channel Domain III-IV Linker Couples Calciumdependent Calmodulin Binding to Inactivation Gating. J. Biol. Chem. 284 (48), 33265-33274. doi: 10.1074/jbc.M109.052910

Sarhan, M. F., Tung, C. C., Van Petegem, F., and Ahern, C. A. (2012). Crystallographic basis for calcium regulation of sodium channels. Proc. Natl. Acad. Sci. U. S. A. 109 (9), 3558-3563. doi: 10.1073/pnas.1114748109

Scanley, B. E., Hanck, D. A., Chay, T., and Fozzard, H. A. (1990). Kinetic-analysis of single sodium-channels from canine cardiac purkinje-cells. J. Gen. Physiol. 95 (3), 411-437. doi: 10.1085/jgp.95.3.411

Scheuer, T. (2011). Regulation of sodium channel activity by phosphorylation. Semin. Cell Dev. Biol. 22 (2), 160-165. doi: 10.1016/j.semcdb.2010.10.002

Schillinger, W., Teucher, N., Christians, C., Kohlhaas, M., Sossalla, S., Van Nguyen, P., et al. (2006). High intracellular $\mathrm{Na}+$ preserves myocardial function at low heart rates in isolated myocardium from failing hearts. Eur. J. Heart Fail. 8 (7), 673-680. doi: 10.1016/j.ejheart.2006.01.013

Scirica, B. M., Morrow, D. A., Hod, H., Murphy, S. A., Belardinelli, L., Hedgepeth, C. M., et al. (2007). Effect of ranolazine, an antianginal agent with novel electrophysiological properties, on the incidence of arrhythmias in patients with non ST-segment elevation acute coronary syndrome: results from the Metabolic Efficiency With Ranolazine for Less Ischemia in Non ST-Elevation Acute Coronary Syndrome Thrombolysis in Myocardial Infarction 36 (MERLIN-TIMI 36) randomized controlled trial. Circulation 116 (15), 16471652. doi: 10.1161/CIRCULATIONAHA.107.724880

Shimizu, W., and Antzelevitch, C. (1997). Sodium channel block with mexiletine is effective in reducing dispersion of repolarization and preventing torsade des pointes in LQT2 and LQT3 models of the long-QT syndrome. Circulation 96 (6), 2038-2047. doi: 10.1161/01.CIR.96.6.2038

Shimizu, W., and Antzelevitch, C. (1999a). Cellular basis for long QT, transmural dispersion of repolarization, and torsade de pointes in the long QT syndrome. J. Electrocardiol. 32 (Suppl), 177-184. doi: 10.1016/s0022-0736(99)90077-8

Shimizu, W., and Antzelevitch, C. (1999b). Cellular and ionic basis for T-wave alternans under long-QT conditions. Circulation 99 (11), 1499-1507. doi: 10.1161/01.cir.99.11.1499

Shimoda, L. A., and Polak, J. (2011). Hypoxia. 4. Hypoxia and ion channel function. Am. J. Physiol. Cell Physiol. 300 (5), C951-C967. doi: 10.1152/ ajpcell.00512.2010

Shryock, J. C., Song, Y. J., Rajamani, S., Antzelevitch, C., and Belardinelli, L. (2013). The arrhythmogenic consequences of increasing late I-Na in the cardiomyocyte. Cardiovasc. Res. 99 (4), 600-611. doi: 10.1093/cvr/cvt145

Sicouri, S., Belardinelli, L., and Antzelevitch, C. (2013). Antiarrhythmic effects of the highly selective late sodium channel current blocker GS-458967. Heart Rhythm. 10 (7), 1036-1043. doi: 10.1016/j.hrthm.2013.03.023
Sipido, K. R., Bito, V., Antoons, G., Volders, P. G., and Vos, M. A. (2007). "Na/Ca exchange and cardiac ventricular arrhythmias," in Sodium-Calcium Exchange and the Plasma Membrane Ca2+-Atpase in Cell Function: Fifth International Conference, vol. 1099 . Eds. A. Herchuelz, M. P. Blaustein, J. Lytton and K. D. Philipson (Annals of the New York Academy of Sciences), 339-348.

Song, J. H., Huang, C. S., Nagata, K., Yeh, J. Z., and Narahashi, T. (1997). Differential action of riluzole on tetrodotoxin-sensitive and tetrodotoxinresistant sodium channels. J. Pharmacol. Exp. Ther. 282 (2), 707-714.

Song, Y., Shryock, J. C., Wu, L., and Belardinelli, L. (2004). Antagonism by ranolazine of the pro-arrhythmic effects of increasing late INa in guinea pig ventricular myocytes. J. Cardiovasc. Pharmacol. 44 (2), 192-199. doi: 10.1097/ 00005344-200408000-00008

Song, Y., Shryock, J. C., Wagner, S., Maier, L. S., and Belardinelli, L. (2006). Blocking late sodium current reduces hydrogen peroxide-induced arrhythmogenic activity and contractile dysfunction. J. Pharmacol. Exp. Ther. 318 (1), 214-222. doi: 10.1124/jpet.106.101832

Song, Y., Shryock, J. C., and Belardinelli, L. (2008). An increase of late sodium current induces delayed afterdepolarizations and sustained triggered activity in atrial myocytes. Am. J. Physiol. Heart Circ. Physiol. 294 (5), H2031-H2039. doi: 10.1152/ajpheart.01357.2007

Sossalla, S., Wagner, S., Rasenack, E. C., Ruff, H., Weber, S. L., Schondube, F. A., et al. (2008). Ranolazine improves diastolic dysfunction in isolated myocardium from failing human hearts-role of late sodium current and intracellular ion accumulation. J. Mol. Cell. Cardiol. 45 (1), 32-43. doi: 10.1016/j.yjmcc.2008.03.006

Sossalla, S., Kallmeyer, B., Wagner, S., Mazur, M., Maurer, U., Toischer, K., et al. (2010). Altered $\mathrm{Na}(+)$ currents in atrial fibrillation effects of ranolazine on arrhythmias and contractility in human atrial myocardium. J. Am. Coll. Cardiol. 55 (21), 2330-2342. doi: 10.1016/j.jacc.2009.12.055

Sossalla, S., Maurer, U., Schotola, H., Hartmann, N., Didie, M., Zimmermann, W. H., et al. (2011). Diastolic dysfunction and arrhythmias caused by overexpression of CaMKIIdelta $(C)$ can be reversed by inhibition of late $\mathrm{Na}(+)$ current. Basic Res. Cardiol. 106 (2), 263-272. doi: 10.1007/s00395-010-0136-x

Stone, P. H., Gratsiansky, N. A., Blokhin, A., Huang, I. Z., and Meng, L. (2006), Antianginal efficacy of ranolazine when added to treatment with amlodipine: the ERICA (Efficacy of Ranolazine in Chronic Angina) trial. J. Am. Coll. Cardiol. 48 (3), 566-575. doi: 10.1016/j.jacc.2006.05.044

Studenik, C. R., Zhou, Z., and January, C. T. (2001). Differences in action potential and early afterdepolarization properties in LQT2 and LQT3 models of long QT syndrome. Br. J. Pharmacol. 132 (1), 85-92. doi: 10.1038/sj.bjp.0703770

Szentandrassy, N., Kistamas, K., Hegyi, B., Horvath, B., Ruzsnavszky, F., Vaczi, K., et al. (2015). Contribution of ion currents to beat-to-beat variability of action potential duration in canine ventricular myocytes. Pflug. Arch. Eur. J. Physiol. 467 (7), 1431-1443. doi: 10.1007/s00424-014-1581-4

Tan, H. L., Kupershmidt, S., Zhang, R., Stepanovic, S., Roden, D. M., Wilde, A. A. M., et al. (2002). A calcium sensor in the sodium channel modulates cardiac excitability. Nature 415 (6870), 442-447. doi: 10.1038/415442a

Tang, Q., Ma, J. H., Zhang, P. H., Wan, W., Kong, L. H., and Wu, L. (2012). Persistent sodium current and $\mathrm{Na}+\mathrm{H}+$ exchange contributes to the augmentation of the reverse $\mathrm{Na}+\mathrm{Ca} 2+$ exchange during hypoxia or acute ischemia in ventricular myocytes. Pflug. Arch. Eur. J. Physiol. 463 (4), 513-522. doi: 10.1007/s00424-011-1070-y

Tarradas, A., Pinsach-Abuin, M. L., Mackintosh, C., Llora-Batlle, O., Perez-Serra, A., Batlle, M., et al. (2017). Transcriptional regulation of the sodium channel gene (SCN5A) by GATA4 in human heart. J. Mol. Cell. Cardiol. 102, 74-82. doi: 10.1016/j.yjmcc.2016.10.013

Thadani, U., Ezekowitz, M., Fenney, L., and Chiang, Y. K. (1994). Double-blind efficacy and safety study of a novel anti-ischemic agent, ranolazine, versus placebo in patients with chronic stable angina pectoris. Ranolazine Study Group. Circulation 90 (2), 726-734. doi: 10.1161/01.CIR.90.2.726

Trenor, B., Cardona, K., Gomez, J. F., Rajamani, S., Ferrero, J. M.Jr., Belardinelli, L., et al. (2012). Simulation and mechanistic investigation of the arrhythmogenic role of the late sodium current in human heart failure. PloS One 7 (3), e32659. doi: 10.1371/journal.pone.0032659

Ufret-Vincenty, C. A., Baro, D. J., Lederer, W. J., Rockman, H. A., Quiñones, L. E., and Santana, L. F. (2001). Role of Sodium Channel Deglycosylation in the Genesis of Cardiac Arrhythmias in Heart Failure. J. Biol. Chem. 276 (30), 28197-28203. doi: 10.1074/jbc.M102548200 
Undrovinas, A. I., Fleidervish, I. A., and Makielski, J. C. (1992). Inward sodium current at resting potentials in single cardiac myocytes induced by the ischemic metabolite lysophosphatidylcholine. Circ. Res. 71 (5), 1231-1241. doi: 10.1161/ 01.RES.71.5.1231

Undrovinas, A. I., Maltsev, V. A., Kyle, J. W., Silverman, N., and Sabbah, H. N. (2002). Gating of the late $\mathrm{Na}+$ channel in normal and failing human myocardium. J. Mol. Cell Cardiol. 34 (11), 1477-1489. doi: 10.1006/jmcc.2002.2100

Undrovinas, A. I., Belardinelli, L., Undrovinas, N. A., and Sabbah, H. N. (2006). Ranolazine improves abnormal repolarization and contraction in left ventricular myocytes of dogs with heart failure by inhibiting late sodium current. J. Cardiovasc. Electrophysiol. 17 (Suppl 1), S169-S177. doi: 10.1111/ j.1540-8167.2006.00401.x

Vacher, B., Pignier, C., Letienne, R., and Verscheure, Y. (2009). Le Grand B. F 15845 inhibits persistent sodium current in the heart and prevents angina in animal models. Br. J. Pharmacol. 156 (2), 214-225. doi: 10.1111/j.1476-5381.2008.00062.x

Valdivia, C. R., Chu, W. W., Pu, J. L., Foell, J. D., Haworth, R. A., Wolff, M. R., et al. (2005). Increased late sodium current in myocytes from a canine heart failure model and from failing human heart. J. Mol. Cell Cardiol. 38 (3), 475-483. doi: 10.1016/j.yjmcc.2004.12.012

van Stuijvenberg, L., Yildirim, C., Kok, B. G., van Veen, T. A., Varro, A., Winckels, S. K., et al. (2010). Alternative promoter usage and splicing of the human SCN5A gene contribute to transcript heterogeneity. DNA Cell Biol. 29 (10), 577-587. doi: 10.1089/dna.2009.0999

Wagner, S., Dybkova, N., Rasenack, E. C. L., Jacobshagen, C., Fabritz, L., Kirchhof, P., et al. (2006). Ca2+/calmodulin-dependent protein kinase II regulates cardiac $\mathrm{Na}+$ channels. J. Clin. Invest. 116 (12), 3127-3138. doi: 10.1172/jci26620

Wagner, S., Ruff, H. M., Weber, S. L., Bellmann, S., Sowa, T., Schulte, T., et al. (2011). Reactive oxygen species-activated $\mathrm{Ca} /$ calmodulin kinase IIdelta is required for late $\mathrm{I}(\mathrm{Na})$ augmentation leading to cellular $\mathrm{Na}$ and $\mathrm{Ca}$ overload. Circ. Res. 108 (5), 555-565. doi: 10.1161/CIRCRESAHA.110.221911

Wagner, S., Rokita, A. G., Anderson, M. E., and Maier, L. S. (2013). Redox regulation of sodium and calcium handling. Antioxid. Redox Signal. 18 (9), 1063-1077. doi: 10.1089/ars.2012.4818

Wang, Z., Page, P., and Nattel, S. (1992). Mechanism of flecainide's antiarrhythmic action in experimental atrial fibrillation. Circ. Res. 71 (2), 271-287. doi: 10.1161/01.res.71.2.271

Wang, Q., Shen, J., Splawski, I., Atkinson, D., Li, Z., Robinson, J. L., et al. (1995). SCN5A mutations associated with an inherited cardiac arrhythmia, long QT syndrome. Cell 80 (5), 805-811. doi: 10.1016/0092-8674(95)90359-3

Wang, D. W., Yazawa, K., George, A. L.Jr., and Bennett, P. B. (1996). Characterization of human cardiac $\mathrm{Na}+$ channel mutations in the congenital long QT syndrome. Proc. Natl. Acad. Sci. U. S. A. 93 (23), 13200-13205. doi: 10.1073/pnas.93.23.13200

Wang, D. W., Viswanathan, P. C., Balser, J. R., George, A. L., and Benson, D. W. (2002). Clinical, genetic, and biophysical characterization of SCN5A mutations associated with atrioventricular conduction block. Circulation 105 (3), 341346. doi: $10.1161 / \mathrm{hc} 0302.102592$

Wang, W. P., Ma, J. H., Zhang, P. H., and Luo, A. T. (2007). Redox reaction modulates transient and persistent sodium current during hypoxia in guinea pig ventricular myocytes. Pflug. Arch. Eur. J. Physiol. 454 (3), 461-475. doi: 10.1007/s00424-007-0219-1

Wang, D. W., Desai, R. R., Crotti, L., Arnestad, M., Insolia, R., Pedrazzini, M., et al. (2007). Cardiac sodium channel dysfunction in sudden infant death syndrome. Circulation 115 (3), 368-376. doi: 10.1161/CIRCULATIONAHA.106.646513

Weiss, S. M., and Saint, D. A. (2010). The persistent sodium current blocker riluzole is antiarrhythmic and anti-ischaemic in a pig model of acute myocardial infarction. PloS One 5 (11), e14103. doi: 10.1371/journal.pone.0014103

Weiss, S. M., Dahlstrom, J. E., and Saint, D. A. (2013). Riluzole reduces arrhythmias and myocardial damage induced by coronary occlusion in anaesthetized pigs. Clin. Exp. Pharmacol. Physiol. 40 (12), 856-863. doi: 10.1111/1440-1681.12175

Wingo, T. L., Shah, V. N., Anderson, M. E., Lybrand, T. P., Chazin, W. J., and Balser, J. R. (2004). An EF-hand in the sodium channel couples intracellular calcium to cardiac excitability. Nat. Struct. Mol. Biol. 11 (3), 219-225. doi: $10.1038 / \mathrm{nsmb} 737$

Wu, J. Y., and Corr, P. B. (1994). Palmitoyl carnitine modifies sodium currents and induces transient inward current in ventricular myocytes. Am. J. Physiol. 266 (3), H1034-H1046. doi: 10.1152/ajpheart.1994.266.3.H1034
Wu, L., Shryock, J. C., Song, Y., and Belardinelli, L. (2006). An increase in late sodium current potentiates the proarrhythmic activities of low-risk QTprolonging drugs in female rabbit hearts. J. Pharmacol. Exp. Ther. 316 (2), 718-726. doi: 10.1124/jpet.105.094862

Wu, L., Ma, J., Li, H., Wang, C., Grandi, E., Zhang, P., et al. (2011). Late sodium current contributes to the reverse rate-dependent effect of IKr inhibition on ventricular repolarization. Circulation 123 (16), 1713-1720. doi: 10.1161/ CIRCULATIONAHA.110.000661

Xi, Y. T., Wu, G. R., Yang, L., Han, K., Du, Y., Wang, T. Z., et al. (2009). Increased late sodium currents are related to transcription of neuronal isoforms in a pressure-overload model. Eur. J. Heart Fail. 11 (8), 749-757. doi: 10.1093/ eurjhf/hfp092

Yamamura, K., Muneuchi, J., Uike, K., Ikeda, K., Inoue, H., Takahata, Y., et al. (2010). A novel SCN5A mutation associated with the linker between III and IV domains of $\mathrm{Na}(\mathrm{v}) 1.5$ in a neonate with fatal long QT syndrome. Int. J. Cardiol. 145 (1), 61-64. doi: 10.1016/j.ijcard.2009.04.023

Yang, P., Kupershmidt, S., and Roden, D. M. (2004). Cloning and initial characterization of the human cardiac sodium channel (SCN5A) promoter. Cardiovasc. Res. 61 (1), 56-65. doi: 10.1016/j.cardiores.2003.09.030

Yang, T., Atack, T. C., Stroud, D. M., Zhang, W., Hall, L., and Roden, D. M. (2012). Blocking Scn10a Channels in Heart Reduces Late Sodium Current and Is Antiarrhythmic. Circ. Res. 111 (3), 322-332. doi: 10.1161/circresaha.112.265173

Yang, K. C., Bonini, M. G., and Dudley, S. C.Jr. (2014). Mitochondria and arrhythmias. Free Radic. Biol. Med. 71, 351-361. doi: 10.1016/j. freeradbiomed.2014.03.033

Yao, L., Fan, P., Jiang, Z., Viatchenko-Karpinski, S., Wu, Y., Kornyeyev, D., et al. (2011). Nav1.5-dependent persistent $\mathrm{Na}+$ influx activates CaMKII in rat ventricular myocytes and N1325S mice. Am. J. Physiol. Cell Physiol. 301 (3), C577-C586. doi: 10.1152/ajpcell.00125.2011

Zablocki, J. A., Elzein, E., Li, X., Koltun, D. O., Parkhill, E. Q., Kobayashi, T., et al. (2016). Discovery of Dihydrobenzoxazepinone (GS-6615) Late Sodium Current Inhibitor (Late INai), a Phase II Agent with Demonstrated Preclinical Anti-Ischemic and Antiarrhythmic Properties. J. Med. Chem. 59 (19), 9005-9017. doi: 10.1021/acs.jmedchem.6b00939

Zareba, W., Daubert, J. P., Beck, C. A., Huang, D. T., Alexis, J. D., Brown, M. W., et al. (2018). Ranolazine in High-Risk Patients With Implanted CardioverterDefibrillators: The RAID Trial. J. Am. Coll. Cardiol. 72 (6), 636-645. doi: 10.1016/j.jacc.2018.04.086

Zaza, A., and Rocchetti, M. (2013). The Late Na+ Current - Origin and Pathophysiological Relevance. Cardiovasc. Drugs Ther. 27 (1), 61-68. doi: $10.1007 /$ s10557-012-6430-0

Zhang, T., and Brown, J. H. (2004). Role of Ca2+/calmodulin-dependent protein kinase II in cardiac hypertrophy and heart failure. Cardiovasc. Res. 63 (3), 476486. doi: 10.1016/j.cardiores.2004.04.026

Zhang, Y., Hartmann, H. A., and Satin, J. (1999). Glycosylation Influences Voltage-Dependent Gating of Cardiac and Skeletal Muscle Sodium Channels. J. Membr. Biol. 171 (3), 195-207. doi: 10.1007/s002329900571

Zhou, A., Shi, G., Kang, G. J., Xie, A., Liu, H., Jiang, N., et al. (2018). RNA Binding Protein, HuR, Regulates SCN5A Expression Through Stabilizing MEF2C transcription factor mRNA. J. Am. Heart Assoc. 7 (9), e007802. doi: 10.1161/ JAHA.117.007802

Zygmunt, A. C., Nesterenko, V. V., Rajamani, S., Hu, D., Barajas-Martinez, H., Belardinelli, L., et al. (2011). Mechanisms of atrial-selective block of $\mathrm{Na}(+)$ channels by ranolazine: I. Experimental analysis of the use-dependent block. Am. J. Physiol. Heart Circ. Physiol. 301 (4), H1606-H1614. doi: 10.1152/ ajpheart.00242.2011

Conflict of Interest: The authors declare that the research was conducted in the absence of any commercial or financial relationships that could be construed as a potential conflict of interest.

Copyright (๑ 2020 Horváth, Hézső, Kiss, Kistamás, Magyar, Nánási and Bányász. This is an open-access article distributed under the terms of the Creative Commons Attribution License (CC BY). The use, distribution or reproduction in other forums is permitted, provided the original author(s) and the copyright owner(s) are credited and that the original publication in this journal is cited, in accordance with accepted academic practice. No use, distribution or reproduction is permitted which does not comply with these terms. 